\title{
Sedimentary organic matter characterization of the Whitehill shales (Karoo Basin, South Africa): an integrated quantitative approach using FE-EPMA and LA-ICP-MS
}

\author{
Gelu Costin ${ }^{1}$, Annette E. Götz ${ }^{2 *}$, Katrin Ruckwied ${ }^{3}$
}

${ }^{1}$ Rice University, Department of Earth, Environmental and Planetary Sciences, Houston, Texas 77005, USA

${ }^{2}$ University of Portsmouth, School of Earth and Environmental Sciences, Portsmouth PO1 3QL, United Kingdom

${ }^{3}$ Timewarp Stratigraphy LLC, 1411 Winding Canyon Ct., Katy, Texas 77493, USA

*corresponding author (annette.goetz@port.ac.uk)

\begin{abstract}
Permian black shales of South Africa's Karoo Basin have been classified as potential unconventional gas resources, the Whitehill Formation of the southern basin parts being the main target for future shale gas exploration and production. Here, we present a novel approach of SOM characterization integrating routine palynofacies analysis and high-resolution BSE imaging, modal mineral analysis, quantitative carbon analysis, EPMA trace element analysis, WDS mapping of carbon particles and carbon peak shift method using field emission microprobe as well as LA-ICP-MS trace element analysis. Black shales of the Whitehill Formation intersected in two deep boreholes of the southern Karoo Basin were studied: (1) massive carbonaceous siltstone (borehole KZF-1, southwestern basin) and (2) laminated shale made of alternating silty and clayey-silty laminae (borehole KWV-1, southeastern basin). Palynofacies indicates an outer shelf setting in the southwestern part (KZF-1) and a stratified basin in the southeastern part (KWV-1). The two shale types reveal striking differences in mineralogy, major and trace element concentrations, and shape and texture of organic particles. The EPMA trace element data of SOM show that the concentration of the elements in the organic particles does not correlate with the chemistry of the black shale when SOM is thermally untransformed. However, in the case of thermally affected and mobilized SOM, the organic acid-rich fluids liberated during the transformation and deformation of SOM can differentially dissolve chemical elements from the surrounding minerals. The LA-ICP-MS data show that the Whitehill shales are enriched in $\mathrm{S}, \mathrm{Mn}, \mathrm{Mo}, \mathrm{Ag}, \mathrm{Cd}, \mathrm{Re}, \mathrm{Bi}$ and $\mathrm{U}$ relative to the standard marine mud MAG-1. Shales from the southeastern basin (KWV-1) are strongly depleted in $\mathrm{Cu}, \mathrm{Zn}, \mathrm{As}$ and $\mathrm{Ba}$. The granulometric and mineralogical properties of the shales suggest an outer shelf setting with low-energy sediment fallout and sediment reworking, consistent with the palaeoenvironmental interpretation based on palynofacies analysis. Different burial depths are inferred
\end{abstract}


from different organic textures: KZF-1 shales show organic particles which preserve organic textures, randomly distributed throughout the siltstone, whereas KWV-1 shales show deformed, thermally transformed and mobilized organic particles, located in between distinct laminae. WDS quantitative element mapping allows for identifying various carbon concentrations within the organic particles. This variability of carbon at grain scale may indicate different carbon-hydrogen molecule speciations. The observed peak shift of carbon in EPMA on different textural types of SOM allowed a correlation between the peak shift and the degree of SOM maturation, indicating that this method potentially works as a vitrinite reflectance proxy. Ultimately, the evaluation of the diagenetic conditions of organic-rich shales from different parts of the basin based on textural criteria of the detrital material and organic particles combined with the carbon peak shift in different organic particles contributes to the assessment of the hydrocarbon potential.

Keywords: FE-EPMA; LA-ICP-MS; SOM; black shales; Karoo Basin; South Africa.

\section{Introduction}

Permian black shales of South Africa's Karoo Basin have been identified as unconventional gas resource. The main target for future shale gas exploration and production is the Whitehill Formation of the southern basin parts, between abundant dolerites to the north and the Cape Fold Belt to the south (Decker and Marot, 2012; Decker, 2013; Geel et al., 2013; Mowzer and Adams, 2015; De Kock et al., 2017; Chere et al., 2017). However, a detailed characterization of the sedimentary organic matter (SOM) is required to assess the hydrocarbon potential of target horizons across the basin. In this context, the palynofacies of the different black shales provided vital information on the sedimentary environments in which the potential source rocks formed (Götz et al., 2018). The evolution of porosity and pore geometry in the Whitehill Formation was studied by Chukwuma et al. (2018) using a highresolution field emission electron microscope. The authors found a commonly reported strong positive covariation of porosity and total organic carbon content (TOC) in all their samples. The significant decrease in porosity restricted to samples that experienced advanced maturation was interpreted as evidence that porosity decrease is directly related to late thermal decarboxylation of organic matter, due to re-precipitation of framework grains previously dissolved by organic acid-rich fluids that were generated during thermochemical decarboxylation of the organic matter. However, so far no quantitative approach exists in understanding the characterization of the individual organic particles and their degree of maturation. Our present work fills the gaps in: (a) chemical comparison of the trace elements present in the black shales and in the organic particles, respectively; and (b) estimation of the degree of organic matter maturation and understanding the correlation between the diagenetic thermal evolution of the shales, organic matter maturation and the potential of hydrocarbon generation. Integrating quantitative geochemical data on grain scale, as demonstrated in the present study applying field emission electron probe microanalysis (FE-EPMA) to SOM characterization, allows for ultra-high 
differentiation of organic matter and its maturation stage. This approach refines source rock characterization and is regarded to potentially become a standard tool to assess the hydrocarbon potential of shales. Ultimately, the carbon peak shift in the EPMA technique, controlled by the degree of transformation of the SOM, can be used as a vitrinite reflectance proxy and thus contributes to the assessment of the hydrocarbon potential.

\section{Geological setting}

The Main Karoo Basin of South Africa forms part of a series of Pangean basins along the Panthalassan margin of Gondwana, exhibiting a continuous sedimentary succession from the Pennsylvanian to Middle Jurassic (Johnson et al., 2006). Depositional environments range from glacial (Dwyka Group), to marine and coastal plain (Ecca Group), to non-marine fluvial and aeolian (Beaufort and Stormberg groups), capped by some $1.4 \mathrm{~km}$ of basaltic lavas of the Drakensberg Group (Veevers et al., 1994; Johnson et al., 1996). The retro-arc foreland basin model for the Main Karoo Basin (Catuneanu et al., 1998 ; 2004) is the most commonly accepted, explaining the partitioning of the basin by flexural tectonics into proximal foredeep, central forebulge, and distal backbulge flexural provinces. However, more recent studies propose a transtensional foreland system created by subsidence and tilting in a strike-slip regime (Tankard et al., 2009) and a thin-skinned fold belt that developed from collisional tectonics and distant subduction to the south (Lindeque et al., 2011). As discussed in Tankard et al. (2009), the basin evolution is strongly related to the Archean and Proterozoic basement blocks underlying the Karoo. The development of an early/mid Permian southward-deepening ramp syncline related to lithospheric subsidence facilitated by crustal-scale faults, led to stratigraphic northeastwards thinning of the Prince Albert and Whitehill formations above subsiding Namaqua basement onto the elevated Kaapvaal craton, and merging with the coal-bearing Vryheid Formation. Deeper facies above the southern Namaqua and eastern Natal basement blocks and stratigraphic thinning and deposition in marginal and non-marine settings on Kaapvaal basement in the north occurs during late Cisuralian (early/mid Ecca) times, while Guadalupian/Lopingian (late Ecca/Beaufort) times are characterized by pronounced tectonic unloading and uplift in the southern Karoo and subsidence in the northeast. Indeed, palynofacies data so far available for different parts of the basin reveal a basin architecture from NE to SW with terrestrial lacustrine, fluvio-deltaic, and shallow to deep marine environments during the late Cisuralian and early Guadalupian (Götz et al., 2018). Based on palynostratigraphy, marine black shales of the Prince Albert and Whitehill formations are interpreted as stratigraphic equivalents of the terrestrial coal deposits of the Vryheid Formation (Ruckwied et al., 2014; Götz and Wheeler, 2018). Facies changes within the Whitehill Formation described by Chukwuma and Bordy (2016) indicate also a deepening from the northern towards the southern parts of the basin. The model of a transtensional foreland system created by subsidence and tilting in a strike-slip regime might thus better account for the facies patterns and different depositional environments related to the NE-SW deepening basin 
architecture than partitioning of the basin by flexural tectonics as envisioned in the retro-arc foreland basin model.

\section{Materials and methods}

\subsection{Materials}

Two deep boreholes, recently drilled within the framework of the Karoo Research Initiative (KARIN), intersected the Whitehill Formation in the southwestern and southeastern parts of the Karoo Basin (Fig. 1). Borehole KZF-1, drilled in the Western Cape, penetrated Whitehill shales at a depth of 420 metres below surface (De Kock et al., 2016a). Borehole KWV-1, drilled in the Eastern Cape, encountered the top of the Whitehill Formation at a depth of 2295 metres below surface (De Kock et al., 2016b). These boreholes represent the first deep Karoo boreholes since the SOEKOR exploration drilling undertaken in the 1960's and 1970's (Rowsell and de Swardt, 1976), providing new core material for SOM characterization of organic-rich shales.

Optically, the SOM of the Whitehill shales was studied by routine palynofacies analysis. Then, we conducted high-resolution SE (secondary electrons) and BSE (backscattered electrons) imaging, modal mineral analysis, and quantitative carbon analysis, as well as WDS (wavelength dispersive spectrometry) element mapping of carbon, carbon peak shift measurement, and trace element analysis using a JXA-8530F Hyperprobe with field emission (FE-EPMA). TOC values are taken from De Kock et al. (2016b) and Götz et al. (2018).

\subsection{Methods and analytical conditions}

\subsubsection{Quick identification of mineral types by Energy Dispersive Spectrometry (EDS)}

A first identification of mineral types in the black shales was assisted by EDS analysis at Rice University, Department of Earth, Environmental, and Planetary Sciences, using a JEOL Silicon Drift (SD) X-ray Detector with $10 \mathrm{~mm}^{2}$ active area and $133 \mathrm{eV}$ resolution. The detector is attached to a JEOL JXA 8530F Hyperprobe. The analytical conditions used for EDS analysis were: $15 \mathrm{kV}$ accelerating voltage, 20-50 nA beam current, live time 20 seconds. DeadTime (DT) during the analysis was 35$40 \%$ with count rates ranging from $\sim 45,000$ to $\sim 100,000$. The beam size used was "spot" size $(\sim 200$ $\mathrm{nm}$ ) for micrometre-scale particles and defocused beam (square area of 10-50 micrometres) for larger organic particles. The EDS spectra were compared to spectra of known minerals, whereas the semiquantitative EDS analyses were normalized to appropriate numbers of oxygen atoms in order to easily recognize minerals by stoichiometry.

\subsubsection{Quantitative Electron Probe Micro-Analysis (EPMA) data acquisition: bulk analysis of black} shales and in situ analysis of major, minor and trace elements in the organic particles

The advantage of "in situ" analysis of individual organic particles of micrometre size by EPMA resides in the simple fact that using a thin beam of electrons we obtain the concentration of the major, minor 
and trace elements contained in the organic matter only and not in the rock as a whole, as in the LAICP technique. It is well known the difficulty of measuring light elements using the EPMA technique, especially carbon (Bustin et al., 1993, 1996; Wei et al., 2018). For light elements, lower voltage and currents should be used in order to minimize the absorption of the low energy X-rays produced by the light elements. However, such conditions are not at all optimum for analyzing heavy trace elements in organic matter, and high voltage and beam currents should be used, with the risk that the major elements (e.g. carbon) are partially burned/volatilized. For this reason, three separate EPMA analytical sessions were performed, each with a different analytical setup: (i) one session for "bulk" analysis of the rock, using a very large beam, and two sessions for "in situ" analysis of the organic particles; (ii) one for major, minor and few light trace elements (e.g. N, O); and (iii) trace element analysis. The quantitative EPMA data acquisition was carried out at Rice University, Department of Earth, Environmental, and Planetary Sciences, on a Jeol JXA 8530F Hyperprobe, equipped with a Schottky field emission gun and using 5 Wavelength Dispersive Spectrometers (WDS). The standard reference materials used were: BN for $\mathrm{N}$, graphite for $\mathrm{C}$, quartz for $\mathrm{SiO}_{2}$, periclase for $\mathrm{O}$ and $\mathrm{Mg}$, olivine for $\mathrm{Mg}$ and $\mathrm{Fe}$, rhodonite for $\mathrm{Mn}$, chromite for $\mathrm{Cr}$, plagioclase for $\mathrm{Ca}$ and $\mathrm{Al}$, jadeite for $\mathrm{Na}$, orthoclase for $\mathrm{K}$, apatite for $\mathrm{P}$, graphite for $\mathrm{C}$, pyrite for $\mathrm{S}$, germanium metal for Ge, GaAs for As, uranium metal for $\mathrm{U}$ and tungsten metal for $\mathrm{W}$. Analytical conditions employed for "bulk rock" analysis were: accelerating voltage $15 \mathrm{kV}$, beam current $20 \mathrm{nA}$, beam size 60 micrometres. Eight to ten analyses were acquired for each sample, in order to produce a relevant average for each sample. Since carbon was not a target of this elemental analysis, the samples were coated with a thin film of 20-25 nm of graphite. ZAF matrix correction was employed for quantification. The totals of the analyses are significantly different from $100 \mathrm{wt} \%$. The difference is mainly given by the volatile components, i.e. $\mathrm{H}_{2} \mathrm{O}$ and $\mathrm{OH}$ in hydrous minerals, $\mathrm{H}$ from the carbohydrates resulting from the interaction of the electron beam with the organic matter, and $\mathrm{CO}_{2}$ in carbonates.

In situ electron microprobe analysis of the organic particles targeted the major (carbon), minor or trace elements ( $\mathrm{Si}, \mathrm{Al}, \mathrm{Fe}, \mathrm{Mn}, \mathrm{Mg}, \mathrm{Ca}, \mathrm{Na}, \mathrm{K}, \mathrm{P}, \mathrm{S}$ ) and light trace elements (N, O). The analytical conditions used for this analysis were similar to those reported in Wei et al. (2018) except that we used a lower beam current and somewhat different counting times. The following analytical conditions were used: $15 \mathrm{kV}$ accelerating voltage, $10 \mathrm{nA}$ beam current and variable beam size of 0.5-20 micrometres since the size of the beam was constrained by the size of the organic particle measured. Samples were coated with a $20 \mathrm{~nm}$ thin film of aluminum metal. The counting time used were 40 seconds $(20$ seconds on peak and 10 seconds on each lower and upper background, respectively), except for C, O, and N. For $\mathrm{C}$, lower counting times were used ( 10 seconds on peak and 5 seconds on each background) in order to lower the carbon deposition due to cracking of the carbon-based molecules from the sample chamber atmosphere by the hot beam. The $\mathrm{N}$ and $\mathrm{O}$ were analyzed using much higher counting times (100 seconds on peak and 80 seconds on each background) in order to decrease the detection limit and improve the analytical standard deviation. PhiRoZ correction matrix was employed for quantification. 
After careful reference material calibration, secondary standards were run as unknown, in order to evaluate possible peak overlapping effects. The interference for each element was then corrected by subtracting from the counts of the measured (interfered) element a number of counts equal with the number counts of the interfering element, multiplied by a coefficient $\mathrm{k}$. The coefficient $\mathrm{k}$ was calculated after evaluating the interferences when analyzing pure standards, as $\mathrm{k}=$ counts of the interfering element/counts of the interfered element. The following corrections routines were applied: $\mathrm{O}$ $($ corrected $)=\mathrm{O}($ total net counts $)-0.0225 \mathrm{~N}$ (net counts) $\mathrm{O}($ corrected $)=\mathrm{O}$ (total net counts $)-0.003$ $\mathrm{C}$ (total net counts). Analyses with abnormally high nitrogen values were neglected due to possible contamination with nitrogen from the resin (e.g. Ward et al., 2008). The interferences between $\mathrm{N}$ in high C materials (e.g. Bustin et al., 1993; 1996) as well as other interferences were treated as explained below. The routines were applied using JEOL software and used first on secondary standards so that the pure standards can be reproduced without interferences, then were applied to the coal trace analysis routine.

The heavy trace elements measured within the organic particles were Ti, Cr, V, Ge, As, U, and W. The analytical conditions employed are $25 \mathrm{kV}$ acceleration voltage, $50 \mathrm{nA}$ probe current, and electron beam size between 1 to 30 micrometres depending on the size of the analyzed grains. The minor and major elements present in the organic particles or adjacent silicate or carbonate particles, such as $\mathrm{Si}, \mathrm{C}, \mathrm{Fe}$, $\mathrm{Mg}, \mathrm{Ca}$, and $\mathrm{Mn}$, were added to the analysis using lower counting times (10 seconds per peak and 5 seconds per each upper and lower background, respectively). These elements were added to the recipe list of the analysis for two reasons: a) they give an indication of the beam penetration into a silicate or carbonate when analysing micrometre scale organic particles; aberrant values of any of these elements (e.g. very high deviation from the average) in the analyses indicate that the beam went through the organic particle, and surrounding silicates or carbonates were sampled by the beam. Such analyses were ignored; b) the presence of these elements in the organic particle analysis would better resolve the matrix correction when analyzing trace elements and PhiRoZ matrix correction was employed for quantification. The counting time for Ti, Cr, V, Ge, As, U, and W was 100 second on peak and 50 seconds on each lower and upper background. The elements $\mathrm{O}, \mathrm{S}, \mathrm{U}$, and $\mathrm{W}$ were analyzed in a differential mode in order to avoid peak interferences with lower orders X-ray lines produced by other elements.

The WDS quantitative element mapping of the organic particles was acquired at $15 \mathrm{kV}$ and $50 \mathrm{nA}$ in stage mode, using $30 \mathrm{~ms}$ dwell time.

3.2.3. Trace element analysis of black shales by Laser Ablation Inductively Coupled Plasma Mass Spectrometry (LA-ICP-MS)

Trace elements in black shales were analyzed using LA-ICP-MS and EPMA. Due to different beam size limitations of the two methods $(<1$ micrometre for EPMA and ca. 60 micrometres for LA-ICPMS), the trace elements in micrometre scale particles cannot be analyzed with LA-ICP-MS. Therefore, 
the "bulk" trace elements in black shales were analyzed using LA-ICP-MS, and the trace elements in the individual micrometre to millimetre scale organic particles were analyzed using EPMA. The results cannot be comparable since LA-ICP-MS gives the trace element content of the rock and EPMA the trace element content of the organic particle. Trace element analysis of black shale by LA-ICP-MS was performed using a Thermo Finnigan Element2, single-collector, sector field ICP-MS (Thermo Fisher Scientific, Waltham, MA, USA), coupled to a New Wave Research, frequency-quintupled (213 nm) Nd:YAG laser system (Electro Scientific Industries, Inc. Portland, OR, USA) in the Department of Earth, Environmental, and Planetary Sciences, Plasma Laboratory at Rice University. The operating conditions were: wavelength $213 \mathrm{~nm}$, energy density $2-3 \mathrm{~J} \mathrm{~cm}^{-2}$, pulse duration $5 \mathrm{~ns}$, carrier gas $\mathrm{He}$, ablation pattern as single spot, laser beam size $55 \mu \mathrm{m}$, repetition rate $10 \mathrm{~Hz}$. The RF power of the Thermo Finnigan Element2 ICP-MS was $1250 \mathrm{~W}$. The gas flows were coupled at a T-junction prior to the plasma torch. Each individual analysis incorporated a $30 \mathrm{~s}$ background acquisition followed by 120 $\mathrm{s}$ spot analysis. The isotopes measured include ${ }^{11} \mathrm{~B},{ }^{23} \mathrm{Na},{ }^{26} \mathrm{Mg},{ }^{27} \mathrm{Al},{ }^{30} \mathrm{Si},{ }^{31} \mathrm{P},{ }^{32} \mathrm{~S},{ }^{39} \mathrm{~K},{ }^{43} \mathrm{Ca},{ }^{49} \mathrm{Ti},{ }^{51} \mathrm{~V}$, ${ }^{52} \mathrm{Cr},{ }^{55} \mathrm{Mn},{ }^{57} \mathrm{Fe},{ }^{59} \mathrm{Co},{ }^{60} \mathrm{Ni},{ }^{63} \mathrm{Cu},{ }^{66} \mathrm{Zn},{ }^{72} \mathrm{Ge},{ }^{73} \mathrm{Ge},{ }^{75} \mathrm{As},{ }^{77} \mathrm{Se},{ }^{88} \mathrm{Sr},{ }^{95} \mathrm{Mo},{ }^{107} \mathrm{Ag},{ }^{111} \mathrm{Cd},{ }^{118} \mathrm{Sn},{ }^{121} \mathrm{Sb}$, ${ }^{137} \mathrm{Ba},{ }^{185} \mathrm{Re},{ }^{197} \mathrm{Au},{ }^{202} \mathrm{Hg},{ }^{208} \mathrm{~Pb},{ }^{209} \mathrm{Bi},{ }^{232} \mathrm{Th}$ and ${ }^{238} \mathrm{U}$. NIST 610 glass was used as the calibration standard and ${ }^{30} \mathrm{Si}$ was used as the internal standard isotope.

\section{Results and discussion}

\subsection{Palynofacies}

Palynofacies analysis of Whitehill shales from the northern and southern Karoo Basin permits marginal marine and outer shelf deposits to be distinguished (Götz et al., 2018; Fig. 1). Outer shelf deposits are dominated by equi-dimensional, opaque phytoclasts and AOM, and marginal marine deposits reveal the highest phytoclast percentages (Fig. 2), with the highest variability in size and shape, and opaque and translucent particles present. In the south-western basin (borehole KZF-1), the sedimentary organic matter content of the Whitehill shales indicates an outer shelf setting with moderate marine phytoplankton percentages (acritarchs, prasinophytes), good AOM preservation, low terrestrial input, and low spores/bisaccates ratios, data plotting in field VII of the AOM-Phytoclast-Palynomorph ternary diagram (Fig. 2). In the south-eastern part (borehole KWV-1), palynofacies suggests a stratified basin with low marine phytoplankton percentages (exclusively prasinophytes), good AOM preservation, high terrestrial input, and a moderate spores/bisaccates ratio, data plotting in field IVa. Further to the south (Ecca Pass), the percentage of AOM increases, data plotting in field IVb. In contrast, palynofacies data from Whitehill shales of the northern part of the basin (SOEKOR borehole DP 1/78) reveal a shallow marine, restricted marginal setting with low marine phytoplankton percentages (leiospheres, prasinophytes), low AOM preservation, high phytoclast input, and a high spores/bisaccates ratio, data plotting in field II of the AOM-Phytoclast-Palynomorph ternary diagram (Fig. 2).

\subsection{Petrography, organic particle morphology, diagenesis, and porosity}


Whitehill shales from borehole KZF-1 are massive, with no lamination or layering observed. EDS analysis shows that they are composed of detrital grains of diverse minerals. The modal mineralogy and particle size for each rock are given in Table 1. The volume percentage of each phase was estimated by image analyses (pixel counting) from five BSE images representing KZF-1 shale and ten BSE images of laminated KWV-1 shale (five for each type of lamina). The high resolution and high contrast BSE images were analysed (pixel counting) using Adobe Acrobat software. The grain size was measured as the longest length of each type of grain. An average was calculated for each phase in each BSE image, and then the weight average was calculated, for each type of phase, in each sample (Table 1). The BSE images show that the organic particles are rare and dispersed throughout the rock (Fig. 3). From these observations it is inferred that sample KZF-1 has much more silt-sized clasts ( $\sim 96 \mathrm{vol} \%)$ than clay particles $(\sim 4$ vol \%), with $\sim 8$ vol \% carbonate clasts. Following the grain size classification of Folk (1965), the rock represents a silt. Due to non-evident fissility or internal layered orientation of the particles, and combined with the compositional criteria, the rock can be also classified as carbonaceous siltstone or calcareous tarl (terrigenous-argillaceous), using the classification of Milliken (2014). The organic particles show various sizes and shapes (Fig. 4): They can be few micrometre in size, rounded with no internal texture (Fig. 4a), represented by phytoclasts or amorphous organic matter as type II kerogen according to van Krevelen, (1993); or tens of micrometres in size showing irregular shape with some weak, distorted internal texture as inertinite maceral type (Fig. 4b); or even millimetre sized, elongated needle-shaped, showing transversal dislocations (Fig. 4c) and internal cellular texture, represented by carbonized plant fragments as liptinite maceral type, most probably type III kerogen (Fig. 4d). Both, organic particles and the size distribution of mineral clasts point to a mixed source area: (1) siliciclastic inferred from micrometre-sized quartz and feldspar which can be correlated with the micrometre-sized, rounded organic particles without internal texture; (2) carbonatic inferred from the hundred micrometre to millimetre size of anhedral ankerite correlating with the hundred micrometre to millimetre size organic particles, which preserved original shape and internal texture.

Whitehill shales from borehole KWV-1 are layered and composed of millimetre thick laminae of different mineral composition (Fig. 5). These laminae are represented by siltstones and clayey siltstones, where clay is detrital. However, given the fine lamination and the rock being easily fissile along the lamination planes, the whole rock comprising alternating laminae can be classified as (laminated black) shale (Folk, 1965) or laminated tarl (Milliken, 2014). Some laminae (e.g. Lamina 1 in Fig. 5) are mainly made of weakly oriented micrometre-sized matrix of clay (illite), pigmented with dispersed micrometresized pyrrhotite, in which larger (20-30 micrometres) anhedral quartz and irregular crystals of titanite ( 50 micrometres) float. This type of laminae is clayey shale whether other laminae (e.g. Lamina 2 ) are siltites, mostly made of plagioclase grains and rare titanite, pyrrhotite, quartz and organic particles. The organic particles are mainly located in-between the distinct laminae, they are elongated, having a vein-like shape, with no visible internal texture. The thickness of the vein-like organic particles is 1-10 micrometres (OP in-between laminae 1 and 2; Fig. 5). The individual organic particles in the laminae 
show rounded and angular shapes with no internal texture, looking "squeezed" between the mineral particles (Fig. 6a). Their appearance suggests that they underwent deformation and possible associated thermal transformation. These particles are located near the boundaries between distinct laminae, boundaries which are marked by a denser network of vein-like organic particles without internal organic texture (Fig. 6b). The vein-like shape of these particles and absence of internal organic texture suggest that the organic matter was deformed, probably underwent thermal transformation and migrated towards the laminae boundaries.

The association of angular, chemically zoned Fe-bearing carbonates and spatial related rounded framboidal pyrite in KZF-1 shales (Fig. 3) is relevant for understanding the diagenetic physical conditions. The angular fragments of carbonates which show rim zones depleted in $\mathrm{Fe}$, indicate that the carbonates were not dissolved, but rather they were involved within a reaction with the pore fluid. The chemical zonation of carbonates is therefore linked to a diagenetic reaction where Fe diffused out of the carbonate within the pore fluid, feeding the new formed framboidal pyrite. Moreover, the development of framboidal pyrite around some organic particles suggests a genetic link between SOM and pyrite, related to late formation of framboidal pyrite in local anoxic conditions, a process which reflects a diagenetic, rather than a depositional process (Schulz et al., 2018).

The backscattered electron image shows that the silt fraction is poorly sorted, with angular to subangular clasts which clearly show that the porosity is mainly controlled by the intergranular pores (interconnected voids around clasts and matrix grains controlled by point- or short linear contacts between grains). The contribution of the organic porosity (organic matter - OM - pores after Schieber, 2010), dissolution pores (or carbonate dissolution - CD - pores after Schieber, 2010), and intra-granular pores (or matrix inter-crystalline; e.g. Milner et al., 2010) are subordinate contributors to the effective porosity.

KWV-1 shales, characterized by thermally transformed and mobilized SOM, show that the porosity is mainly controlled by the inter-laminar discontinuities (Figs. 5, 6b), planes also used by the organic matter during its displacement. Intra-crystalline, organic porosity (e.g. Schieber et al., 2010; Chukwuma et al., 2018) has a much higher contribution to the rock porosity. Here, the inter-crystalline porosity is much lower compared to the KZF-1 shales, and, by contrast, the organic porosity, with a high degree of interconnectivity, controls the effective porosity of the rock. According to these observations, we can advocate that the porosity of SOM-bearing silty rocks, where the SOM is thermally untransformed, is controlled by inter-crystalline pores, whereas the porosity of SOM-transformed (kerogen) laminar clayey rocks is controlled by inter-laminar discontinuities and organic intra-grain porosity.

Our observations regarding the evolution of porosity generally agree with the findings of Chukwuma et al. (2018), who, using high-resolution FE-SEM imaging combined with EDS analyses found that porosity positively correlates with the degree of SOM maturation in Whitehill shales. However, we draw attention to one of their findings which stipulates that a drastic decrease in porosity is observed in 
some rocks linked to thermal decarboxylation of organic matter, correlating with the infilling of pores by fibrous grains (including carbonates, clays, silicates, and phosphates) generated by re-precipitation of framework grains previously dissolved by organic acid-rich fluids. Our observations do not support this interpretation, as the framework grains (even very sensitive carbonates) in highly thermally transformed SOM-bearing rocks do not show dissolution and re-precipitation effects. These effects should have been observed as chemically incongruent dissolution (e.g. Barman et al., 1992) and reprecipitation with new phases nucleating on, and overgrowing the existing framework grains. Huang and Keller (1970) experimentally showed that Al dissolved proportionately more than Si from feldspar in all the organic acid-rich fluids (incongruent dissolution) and its precipitation should produce caolinite or other Al-rich phases, which were not observed in our samples.

\subsection{Major and minor element analysis of the black shales using EPMA}

The EPMA data for the samples from boreholes KZF-1 and KWV-1 are presented in Tables 2A and $2 \mathrm{~B}$, respectively. The analyses were acquired using large beam size (60 micrometres) and then averaged for each sample. As hydrogen ( or $\mathrm{H}_{2} \mathrm{O}$ ) and volatile $\mathrm{CO}_{2}$ cannot be measured by EPMA, the totals of analysis are below $100 \mathrm{wt} \%$. The difference (100 wt $\%$ - Totals) represents a good estimation of the $(\mathrm{H} 2 \mathrm{O}+\mathrm{CO} 2)$, almost equivalent to LOI (loss on ignition) in X-ray fluorescence spectrography. The totals of the analysis show small differences between the two shale types $(90.85 \pm 1.10 \mathrm{wt} \%$ and 92.52 \pm 1.03 wt \% for KZF-1 and KWV-1 shales, respectively), suggesting a similar ( $\mathrm{H} 2 \mathrm{O}+\mathrm{CO} 2)$ concentration in both shales. KZF-1 shales show higher values of $\mathrm{SiO}_{2}, \mathrm{Al}_{2} \mathrm{O}$ 3, $\mathrm{Na}_{2} \mathrm{O}$, and $\mathrm{K}_{2} \mathrm{O}$, suggesting the abundance of alkaline feldspars and quartz of detrital origin. Significant high $\mathrm{K}_{2} \mathrm{O}$ can also be correlated with the illite clay fraction, while a slight correlation of $\mathrm{Ca}$ and $\mathrm{Fe}$ (not shown here) can be associated with the presence of ankerite identified by EDS analysis. KWV-1 shales are richer in $\mathrm{FeO}, \mathrm{MgO}, \mathrm{MnO}, \mathrm{CaO}, \mathrm{P}_{2} \mathrm{O}_{5}$ (all in wt \%) and $\mathrm{S}$ (atom wt \%), clearly suggesting a different mineral composition compared to the KZF-1 shales, being richer in mafic minerals, apatite, and sulfides. The $\mathrm{MgO} \#$ (molecular $\mathrm{MgO} /(\mathrm{MgO}+\mathrm{FeO})$ ) calculated for the rocks is useful for comparing the mafic component of the rocks, while the $\left(\mathrm{Na}_{2} \mathrm{O}+\mathrm{CaO}\right)$ can differentiate between the plagioclase components. A diagram $\mathrm{MgO} \#$ vs. $\left(\mathrm{Na}_{2} \mathrm{O}+\mathrm{CaO}\right)$ shows the differences in the mafic and feldspar components of the analyzed samples (Fig. 7a). Aluminum, being an insoluble element in exogenous conditions, is a useful indicator of the detrital component of the rocks, mostly indicating the feldspar and muscovite components of the rocks. A diagram $\mathrm{Al}_{2} \mathrm{O}_{3}$ vs. $\left(\mathrm{Na}_{2} \mathrm{O}+\mathrm{CaO}\right)$ distinguishes between $\mathrm{KZF}-1$ and $\mathrm{KWV}-1$ shales, as well as between the laminae 1 and 2 in sample KWV-1 (Fig. 7b). The chemical differences between the KZF-1 and KWV-1 shales can be explained by different source areas, while the difference between the laminae in sample KWV-1 showing different $\left(\mathrm{Na}_{2} \mathrm{O}+\mathrm{CaO}\right)$ and $\mathrm{Al}_{2} \mathrm{O}_{3}$ indicates a different proportion of feldspar and illite in the laminae, a difference which is obvious when taking into account the chemical composition of a feldspar-rich siltite and an illite-rich clay rock. The chemical (and mineralogical) difference between the laminae in sample KWV-1 can be explained by hydrodynamic 
sorting, rather than by a different source area; e.g. $\mathrm{MgO \#}$ is very similar in both laminae, but $\mathrm{Al}_{2} \mathrm{O}_{3}$ and $\left(\mathrm{Na}_{2} \mathrm{O}+\mathrm{CaO}\right)$ shows variability.

\subsection{In situ trace element analysis of the organic particles}

The results of the trace element analysis of the organic particles in shales from boreholes KZF-1 and KWV-1 are presented in Tables 3A and 3B, respectively. It is noticed that KZF-1 shales contain a lower concentration of $\mathrm{Si}, \mathrm{Al}, \mathrm{Fe}, \mathrm{Mn}, \mathrm{Mg}, \mathrm{Ca}, \mathrm{N}, \mathrm{K}, \mathrm{S}$ and $\mathrm{O}$ than $\mathrm{KWV}-1$ shales. Elements such as $\mathrm{V}$ and $\mathrm{N}$ are similar in the organic particles from both samples, whereas elements $\mathrm{Ge}, \mathrm{As}, \mathrm{Ti}, \mathrm{U}$, and $\mathrm{W}$ are close or below the detection limit. Interesting, but expected, is that the chemical composition of the organic particles does not correlate with the composition of the black shales. Comparing the data given in Tables 2A and 2B (composition of the black shales) with those listed in Tables 3A and 3B (composition of the organic particles), we notice that even KZF-1 shales show higher concentrations in $\mathrm{Si}, \mathrm{Al}, \mathrm{Na}$, and $\mathrm{K}$. These elements are present in lower concentration in the organic particles from KZF-1 shales compared to the organic particles in $\mathrm{KWV}-1$ shales. Elements such as $\mathrm{Fe}, \mathrm{Mn}, \mathrm{Mg}, \mathrm{Ca}$, and $\mathrm{S}$ are present in higher concentration in KWV-1 shales richer in mafic minerals and sulfides, and where the organic particles were thermally transformed and mobilized/deformed. We suggest that the transformation, deformation, and migration of the organic matter in sample KWV-1 are associated with the partial dissolution of elements of host minerals by the organic acid-rich fluids (e.g. Lewan and Fisher, 1994). The organic particles from KWV-1 shales are also slightly more oxidized, resulting from thermal transformation of the organic matter during diagenesis. Elements such as Ge, As, $\mathrm{U}$ and $\mathrm{W}$ found to be in very low concentrations (few ppm or even below detection limit of the analysis), clearly suggesting that these elements, although some of them can be associated with the migration of the organic matter (U, e.g. Cumberland et al., 2016; Ge, As e.g. Wei et al., 2018), were not present in the organic matter itself. However, they are present in the rock (see trace element analysis by LA-ICP-MS), suggesting that these elements were present during deposition of the organic matter, but not incorporated in the organic matter.

\subsection{Carbon peak shift in EPMA analysis as a potential vitrinite reflectance proxy}

Liang (1992) was the first to observe a carbon peak shift from diamond to graphite to vitrinite using the EPMA method. By following the same approach, we measured the peak position of carbon in different organic particle types showing evident differences in observable reflectance, in shape and textures present in our samples. Five measurements were done on each type of organic particle and an average measurement of the L-values of the carbon peak position detected a slight but consistent peak shift. Different carbon concentration in each OP is related to different intensity of carbon K $\alpha$ X-ray (given by variable counts per second). However, if the type of carbon-based molecules (bond lengths, inner structure, etc.) would be the same, the carbon peak should have the exact same position on the x-axis (L-value). If different OPs show different peak position (peak shift) it is obvious that the lattice/inner 
structure of the OPs is different. Accordingly, if the textural variability of OPs is related to different maturation degree, then the carbon peak shift determined in the EPMA technique is a direct measure of the degree of OP maturation.

The organic particle types selected for these measurements (Fig. 8) were particles with cellular texture (untransformed organic matter) (OP1) to texture-free organic particles (OP2) in sample KZF-1, and vein-like transformed and partially deformed/mobilized organic particles (OP3) in sample KWV-1. Five L-values measurements of the carbon peak were acquired for each particle type OP1, OP2 and OP3. The average L-values (standard deviation $1 \sigma$ in brackets) are: OP1: $127.864 \mathrm{~mm}( \pm 0.009 \mathrm{~mm})$; OP2: $127.788 \mathrm{~mm}( \pm 0.007 \mathrm{~mm})$; OP3: $127.711 \mathrm{~mm}( \pm 0.008 \mathrm{~mm})$ (Fig. 9). The standard graphite peak was measured in the same EPMA session, $\mathrm{L}=127.677 \mathrm{~mm}$. Such observation is intriguing as it suggests a correlation between the carbon peak shift and the type of the hydrate component in the organic matter. More studies are required in order to quantify the correlation between the carbon peak shift and degree of thermal maturation of the organic matter, which can become a successful vitrinite reflectance proxy. Our preliminary results indicate a good correlation between the carbon peak shift and the degree of thermal transformation of the organic material, where the peak shifts can be easily "referenced" to the peak position of graphite, a common standard in EPMA laboratories. By doing so, we observed that the peak shifts from graphite towards lower wavelength as the organic matter is more texturally transformed and shows higher optical reflectance. Knowing that by thermal transformation of the organic matter hydrocarbon is released, we suggest that the carbon peak shift estimation in different organic particle types can be used as a proxy to assess the maturation of the organic matter, as well as the hydrocarbon potential. Based on our observations and measurements, we suggest that the deformed and vein-like organic particles in shales from borehole KWV-1 have produced more hydrocarbon gas than the organic particles in shales from borehole KZF-1. In contrast, KZF-1 shales, with yet thermally untransformed organic particles, indicate a present potential for hydrocarbon generation, if and where the depth of these shales currently corresponds to the "oil window".

\subsection{WDS element mapping of SOM}

WDS mapping targeted the variation of carbon concentration within the SOM, in order to identify if there is a correlation between the concentration of carbon and some textural features of SOM. Figures $10 \mathrm{a}$ and $10 \mathrm{~b}$ illustrate the carbon quantitative mapping of OP1 and OP3, respectively (see Fig. 8). We notice that the carbon concentration in OP1 (Fig. 10a) is variable inside the organic particle, the variation following the cellular textural features of the grain (e.g. the yellow-orange colours inside the grain and the green margin). The green margin probably reflects a different organic speciation situated at the original/relict margin of the particle. The blue colours at the exterior of the grain reflect an edge effect (artifact related to the thinner margin of the grain). The green areas inside the grain can also be related to different organic speciation following the cellular texture. The carbon map in OP3 (Fig. 10b) shows yellow/orange (higher concentration) in the centre of the vein-like, mobilized SOM, whereas the 
green colour on the margin, as well as in the proximity of the main "vein-like" SOM can suggest an organic matter with lower carbon, hence a different speciation.

\subsection{Geochemistry: trace element analysis of the black shales using LA-ICP MS}

Trace elements obtained by LA-ICP MS reflect the geochemical composition of the black shales (Table 4). The elements in Figure 11, arranged from left to right in increasing order of the atomic weight, show a different pattern for the two shale types analyzed. Compared to the standard oceanic mud MAG-1, the Whitehill shales are enriched in $\mathrm{S}, \mathrm{Mn}, \mathrm{Mo}, \mathrm{Ag}, \mathrm{Cd}, \mathrm{Re}, \mathrm{Bi}$ and $\mathrm{U}$. The evident difference between the two boreholes is that shales from borehole KWV-1 are enriched in S and Mn and strongly depleted in $\mathrm{Cu}-\mathrm{Zn}$-As and $\mathrm{Ba}$. The higher $\mathrm{S}$ and very low As concentration can be explained by the higher content of sulfide, which is mostly pyrrhotite and less (As-bearing) pyrite. This interpretation is also supported by the higher concentration of $\mathrm{As}$ (and $\mathrm{Cu}-\mathrm{Zn}$ ) in the shales from borehole KZF-1, elements which can be hosted in pyrite. The higher Mn concentration in the KWV-1 shales is most probably associated with the secondary mafic minerals, while the higher concentrations of Mo and Cd in the KZF-1 shales can be correlated with the organic matter, as most probably do Re and Bi.

Thorium is higher in the KZF-1 shales compared to the KWV-1 shales and positively correlates with $\mathrm{Al}_{2} \mathrm{O}_{3}$ (Fig. 12, left plot). This correlation suggests that thorium is mostly of detrital origin, as $\mathrm{Al}_{2} \mathrm{O}_{3}$ is virtually insoluble in hydrous solutions at low temperature and should be mostly considered as having a detrital origin. The positive correlation of the two elements suggests a similar behaviour during the post-depositional stage (e.g. Th and $\mathrm{Al}$ were not influenced by dissolution and re-mobilisation processes, but they reflect a chemical fingerprint of the detrital source signature). Thorium also correlates positively with uranium (Fig. 12, right plot). It is well known that $\mathrm{U}$ can be enriched in sediments from the marine/sea water (e.g. Gayer et al., 1999). If this would be the case, as U mostly replaces Th in mineral lattices, one would expect to see a negative correlation Th $v s$. U, or a lack of correlation, if $U$ is hosted in lattice vacancies. Our samples show a strong positive correlation between $\mathrm{U}$ and Th, clearly suggesting that both $\mathrm{U}$ and $\mathrm{Th}$ are hosted together in the same detrital minerals, with no modification of $U$ from the sea water. The uranium concentration is much lower compared with other black shales (Devonian shales of West Texas, Harris et al., 2013; Cambrian shales of South China, Pi et al., 2013). This was also observed in black shales from the Permian Irati Formation in Brazil (Santos et al., 2009). Furthermore, the studied Whitehill shales show high values of Pb (Fig. 13, left plot). The chromium values are higher than the nickel values, and the $\mathrm{Cr} / \mathrm{Ni}$ trend is similar to that of the black shales from the Permian Irati Formation in Brazil (Santos et al., 2009). This trend (Fig. 13, left plot) suggests that the detrital source of the Whitehill shales contained a certain ratio of Cr-bearing oxides vs. Ni-bearing sulfides, probably similar to the source area of the black shales from the Permian Irati Formation which is discussed as stratigraphic equivalent of the Whitehill Formation in South Africa (Matos et al., 2001; Santos et al., 2006). The Whitehill shales are poorer in V than all other black shales compared with in this study, while KWV-1 shales contain more vanadium than KZF-1 shales. 
There are two different tendencies of variation of $\mathrm{V}$ with the U/Th ratio (Fig. 13, right plot): a) a relatively constant $\mathrm{U} / \mathrm{Th}$ ratio where $\mathrm{U}>\mathrm{Th}$, also recognized in Cambrian black shales and silty black shales from South China (Pi et al., 2013); b) a constant $\mathrm{U} / \mathrm{Pb}$ ratio, but $\mathrm{U}<\mathrm{Th}$, recognized in the black shales of the Permian Irati Formation, Brazil (Santos et al., 2009) and the Whitehill Formation, South Africa (this study).

A positive correlation of Mo with TOC (Fig. 14), implying that most Mo resides in the organic matter, needs further research with regard to the interpretation of palaeoredox and palaeohydrographic conditions of the basin. No other clear correlation between TOC and other elements was noticed.

\section{Palaeoenvironment interpretation and hydrocarbon potential}

Organic particles of different size and shape with preserved cellular texture identified in KZF-1 shales are plant fragments, transported from the hinterland into the basin. Low spores/bisaccates ratios, moderate marine phytoplankton percentages and good AOM preservation indicate an outer shelf setting, where the dominant depositional processes were low-energy sediment fallout and sediment reworking from the slope. The silicate, oxide, and sulfide clasts are of detrital origin, representing extraclasts. The presence of carbonate grains (allochems) suggests submarine transport. The trace element content of the rock shows a composition enriched in feldspar component and sulfur compared to the marine MAG1 standard, an observation confirmed by the mineralogy of the shale, indicating a significant continental source of the silicate and sulfide fraction.

The grain-supported silt, with no identified cement, indicates that the diagenesis was dominated by compaction. The preservation of cellular texture in most of the organic particles, together with clear contacts between the silicate grains (e.g. missing evidence of any dissolution and precipitation of silica or carbonate) indicate a relatively low temperature of diagenesis. This shale did not achieve the temperature needed for transformation of organic matter into hydrocarbons. However, considering the local tectonic context of the Karoo foreland basin system (Tankard et al., 2009; Lindeque et al., 2011) and the lateral facies variation of these shales (Chukwuma and Bordy, 2016), potential zones where organic matter underwent higher diagenetic temperatures can be identified.

The KWV-1 shales show low marine phytoplankton percentages of prasinophytes, good AOM preservation, high terrestrial input of plant debris, and a moderate spores/bisaccates ratio indicative of a stratified basin. The prominent lamination with alternating laminae of different mineral composition and grain sizes supports the interpretation of a stratified basin as depositional environment where hydrodynamic sorting based on both grain size and density differences is to be expected. Like in the KZF-1 shales, no cement is present and the clay fraction is detrital, and thus the diagenesis was mostly driven by compaction. However, textural (see BSE images) and compositional (see EPMA analyses, carbon peak shift, WDS mapping) transformation of the organic particles suggests that the diagenetic temperature reached by the KWV-1 shales was significantly higher than for the KZF-1 shales. This might point to a higher sedimentation rate and greater burial depth in the southeastern Karoo Basin. 
Consequently, thermal transformation of the organic matter in KWV-1 shales could have been related to generation and production of gaseous hydrocarbon fluids at the time of diagenesis. From the carbon peak shift it can be inferred that the deformed and vein-like organic particles in shales from borehole KWV-1 have produced more hydrocarbon gas than the thermally untransformed organic particles in shales from borehole KZF-1.

\section{Conclusions}

The depositional environment of the analysed Whitehill shales of the southern Karoo Basin, inferred from palynofacies as well as granulometric and mineralogic properties, is the outer shelf with lowenergy sediment fallout and sediment reworking. Analytically, FE-EPMA application to trace element analysis of organic-rich shales enables the characterization of SOM, a huge advantage in comparison to traditional bulk rock trace element analysis. Additionally, very small organic particles can be analyzed, a limitation of LA-ICP-MS application where the size of the laser is usually much larger than the organic particle itself. Trace element analysis of pristine, non-thermally transformed SOM shows chemical compositions which can contrast with the trace elements of the host rocks, clearly suggesting that the trace elements in SOM are not related to the host rock, neither reflect the chemical environment during the sedimentation of SOM. Furthermore, WDS quantitative element mapping permits identification of various carbon concentrations within the organic particles, especially the ones preserving cellular organic textures. This variability of carbon at grain scale indicates different hydrocarbon speciations. The EPMA measurement of the carbon peak shift can be used as a tool to: (a) identify different types of organic matter (different speciation of carbon in organic solid compounds), and (b) evaluate the degree of organic matter transformation (maturation), and thus contributes to the assessment of the hydrocarbon potential of the source rocks. The peak shift of carbon may have potential as a vitrinite reflectance proxy. The WDS quantitative carbon mapping suggests that this method can be used to show the variability of the carbon concentration inside the SOM. Such variability can be ascribed to different organic speciation of carbon related to relict original cellular texture in thermally untransformed SOM, or attributed to zonation of different organic carbon speciation related to the mobility and transport during thermal transformation, deformation and migration of the organic matter. The Whitehill shales are enriched in $\mathrm{S}, \mathrm{Mn}, \mathrm{Mo}, \mathrm{Ag}, \mathrm{Cd}, \mathrm{Re}, \mathrm{Bi}$ and $\mathrm{U}$ relative to the standard marine mud MAG-1. The evident difference between the two shale types is that KWV-1 shales are enriched in $\mathrm{S}$ and $\mathrm{Mn}$ and strongly depleted in $\mathrm{Cu}, \mathrm{Zn}, \mathrm{As}$ and $\mathrm{Ba}$. The positive correlation of Th and $\mathrm{Al}_{2} \mathrm{O}_{3}$ suggests that thorium is mostly of detrital origin. The uranium concentration is much lower compared with black shales from other sites. The chromium values are higher than the nickel values, and the $\mathrm{Cr} / \mathrm{Ni}$ trend suggests that the detrital source of the shales contained a certain ratio of Cr-bearing oxides vs. Nibearing sulfides. The positive correlation of Mo with TOC implies that most Mo resides in the organic matter. This observation needs further research with regard to the interpretation of palaeoredox and palaeohydrographic conditions of the basin. 
We agree with Hacklay and Cardott (2016) that an interconnected organic porosity occurs in the solid bitumen of thermally mature shale reservoirs. However, the authors state the inability of SEM studies to confirm the type of organic matter present. Our work shows that a detailed EPMA approach can complement both high-resolution secondary electron and backscattered electron imaging, and measurements of carbon peak shift in SOM in EPMA method, as a future tool to identify and quantify the nature of the organic matter. However, further studies are necessary to establish a calibration curve of the carbon peak shift in bitumen, various macerals, and kerogen.

\section{Acknowledgements}

This study is part of the research conducted within the framework of the Karoo Research Initiative (KARIN) under the umbrella of the NRF-DST Centre of Excellence for Integrated Mineral and Energy Resource Analysis (CIMERA) hosted by the University of Johannesburg and co-hosted by the University of the Witwatersrand. The use of the EPMA facility at the Department of Earth, Environmental and Planetary Sciences, Rice University, Houston, TX, is kindly acknowledged. We kindly thank Ming Tang for assisting with trace element analyses of black shale using LA-ICP-MS at Rice University, Department of Earth, Environmental and Planetary Sciences. The suggestions and comments of two anonymous reviewers have greatly improved our manuscript.

\section{References}

Barman, A.K., Varadachari, C., Ghosh, K., 1992. Weathering of silicate minerals by organic acids. I Nature of cation solubilization. Geoderma 53, 45-63.

Bustin, R.M, Mastalerz, M., Wilks, K., 1993. Direct determination of carbon, oxygen and nitrogen content in coal using the electron microprobe. Fuel 72, 181-5.

Bustin, R.M., Mastalerz, M., Raudsepp, M., 1996. Electron-probe microanalysis of light elements in coal and other kerogen. Int. J. Coal Geol. 32, 5-30.

Catuneanu, O., 2004. Retroarc foreland systems - evolution through time. J. Afr. Earth Sci. 38, 225242.

Catuneanu, O., Hancox, P.J., Rubidge, B.S., 1998. Reciprocal flexural behaviour and constrasting stratigraphies: a new basin development model for the Karoo retroarc foreland system, South Africa. Basin Res. 10, 417-439.

Chere, N., Linol, B., de Wit, M., Schulz, H.-M., 2017. Lateral and temporal variations of black shales across the southern Karoo Basin - Implications for shale gas exploration. S. Afr. J. Geol. 120, 541-564. 
Chukwuma, K., Bordy, E.M., 2016. Spatiotemporal sedimentary facies variations in the Lower Permian Whitehill Formation, Ecca Group, Karoo Basin. In: Linol, B., de Wit, M.J. (Eds.), Origin and Evolution of the Cape Mountains and Karoo Basin. Regional Geology Reviews, Springer, pp. 101-110.

Chukwuma, K., Bordy, E.M., Coetzer, A., 2018. Evolution of porosity and pore geometry in the Permian Whitehill Formation of South Africa - A FE-SEM image analysis study. Mar. Petrol. Geol. 91, 262-278.

Cumberland, S.A., Douglas, G., Grice, K., Moreau, J.W., 2016. Uranium mobility in organic matterrich sediments: A review of geological and geochemical processes. Earth-Sci. Rev. 159, 160-185.

Decker, J., 2013. The Karoo Basin's shale gas potential. GeoForum, 3-5 July, 2013, Johannesburg.

Decker, J., Marot, J., 2012. Investigation of hydraulic fracturing in the Karoo of South Africa. Annexure A, Resource Assessment, Petroleum Agency SA. Available at: http://www.dmr.gov.za/publications/viewdownload/182/854.html

De Kock, M.O., Beukes, N.J., Götz, A.E., Cole, D., Robey, K., Birch, A., Withers, A., van Niekerk, H.S., 2016a. Progress report on exploration of the southern Karoo Basin through CIMERA-KARIN borehole KZF-1 in the Tankwa Karoo, Witzenberg (Ceres) district. CIMERA-KARIN Open-File Report 2016-1, Johannesburg, 12 pp.

De Kock, M.O., Beukes, N.J., van Niekerk, H.S., Cole, D., Robey, K., Birch, A., Götz, A.E., $2016 b$. Progress report on investigation of the southeastern Main Karoo Basin through CIMERA-KARIN borehole KWV-1 near Willowvale in the Eastern Cape Province. CIMERA-KARIN Open-File Report 2016-2, Johannesburg, 13 pp.

De Kock, M.O., Beukes, N.J., Adeniyi, E.O., Cole, D., Götz, A.E., Geel, C., Ossa, F.-G., 2017. Deflating the shale gas potential of South Africa's Main Karoo Basin. S. Afr. J. Sci. 113, Art. \#20160331, $12 \mathrm{pp}$.

Folk, R.L., 1965. Petrology of Sedimentary Rocks. Hemphill Publishing Company, Austin, TX, 184 pp. 
Gayer, R.A., Rose, M., Dehmer, J., Shao, L-Y., 1999. Impact of sulphur and trace element geochemistry on the utilization of a marine-influenced coal - case study from the South Wales Variscan foreland basin. Int. J. Coal. Geol., 40, 151-174.

Geel, C., Schulz, H.-M., Booth, P., de Wit, M., Horsfield, B., 2013. Shale gas characteristics of Permian black shales in South Africa: results from recent drilling in the Ecca Group (Eastern Cape). Energy Procedia 40, 256-265.

Goldberg, K., Humayun, M., 2016. Geochemical paleoredox indicators in organic-rich shales of the Irati Formation, Permian of the Paraná Basin, southern Brazil. Braz. J. Geol. 46, 377-393.

Götz, A.E., Wheeler, A., 2018. Challenges of Gondwanan marine-nonmarine correlations - a palynological perspective. Paleontol. J. 52, 748-754.

Götz, A.E., Ruckwied, K., Wheeler, A., 2018. Marine flooding surfaces recorded in Permian black shales and coal deposits of the Main Karoo Basin (South Africa): implications for basin dynamics and cross-basin correlation. Int. J. Coal Geol. 190, 178-190.

Hacklay, P.C., Cardott, B.J., 2016. Application of organic petrography in North American shale petroleum systems: A review. Int. J. Coal Geol. 163, 8-51.

Harris, N.B., Mnich, C.A., Selby, D., Korn, D., 2013. Minor and trace element and Re-Os chemistry of the Upper Devonian Woodford Shale, Permian Basin, west Texas: Insights into metal abundance and basin processes. Chem. Geol. 356, 76-93.

Huang, W.H., Keller, W.D., 1970. Dissolution of rock-forming silicate minerals in organic acids: simulated first-stage weathering of fresh mineral surfaces. Am. Mineral. 55, 2076-2094.

Johnson, M.R., Van Vuuren, C.J., Hegenberger, W.F., Key, R., Shoko, U., 1996. Stratigraphy of the Karoo Supergroup in southern Africa: an overview. J. Afr. Earth Sci. 23, 3-15.

Johnson, M.R., van Vuuren, C.J., Visser, J.N.J., Cole, D.I., Wickens, H. de V., Christie, A.D.M., Roberts, D.L., 1997. The Foreland Karoo Basin, South Africa. In: Selley, R.C. (Ed.), Sedimentary Basins of the World: African Basins. Elsevier, Amsterdam, pp. 269-317.

Johnson, M.R., Van Vuuren, C.J., Visser, J.N.J., Cole, D.I., Wickens, H., de, V., Christie, A.D.M., Roberts, D.L., Brandl, G., 2006. Sedimentary rocks of the Karoo Supergroup. In: Johnson, M.R., 
Anhaeusser, C.R., Thomas, R.J. (Eds.), The Geology of South Africa. Geological Society of South Africa, Johannesburg/Council for Geoscience, pp. 461-499.

Lewan, M.D., Fisher, J.B., 1994. Organic Acids from Petroleum Source Rocks. In: Pittman, E.D., Lewan, M.D. (Eds.), Organic Acids in Geological Processes. Springer, Berlin, pp. 70-114.

Liang, L. C., 1992. Carbon Ka peak shift study using an electron probe microanalyzer with a vanadiumcarbon multilayer pseudo-crystal. X-Ray Spectrom. 21, 191-192.

Lindeque, A., De Wit, M.J., Ryberg, T., Weber, M., Chevallier, L., 2011. Deep crustal profile across the southern Karoo Basin and Beattie Magnetic Anomaly, South Africa: An integrated interpretation with tectonic implications. S. Afr. J. Geol. 114, 265-292.

Lucas, S.G., Shen, S.Z., 2018. The Permian timescale: an introduction. In: Lucas, S.G., Shen, S.Z. (Eds.), The Permian Timescale. Geological Society, London, Spec. Publ. 450, 1-19.

Matos, S.L.F., Yamamoto, J.K., Riccomini, C., Hachiro, J., Tassinari, C.C.G., 2001. Absolute dating of Permian ash-fall in the Rio Bonito Formation, Paraná Basin, Brazil. Gondwana Res. 4, 421-426.

Milliken, K., 2014. A compositional classification for grain assemblages in fine-grained sediments and sedimentary rocks. J. Sediment. Res. 84, 1185-1199.

Milner, M., Mclin, R., Petriello, J., 2010. CSUG/SPE 138975: Imaging texture and porosity in mudstones and shales: Comparison of secondary and ion-milled backscatter SEM methods. Canadian Unconventional Resources \& International Petroleum Conference, 1-10.

Mowzer, Z., Adams, S., 2015. Shale gas prospectivity analysis of the southern Main Karoo Basin. Petroleum Agency South Africa contribution to the strategic environmental assessment, Agency report FG 2015, 1-57.

Pi, D.-H., Liu, C.-Q., Shields-Zhou, G.A., Jiang, S.-Y., 2013. Trace and rare earth element geochemistry of black shale and kerogen in the early Cambrian Niutitang Formation in Guizhou province, South China: Constraints for redox environments and origin of metal enrichments. Precambrian Res. 225, $218-229$. 
Rowsell, D.M., de Swardt, A.M.J., 1976. Diagenesis in Cape and Karoo sediments, South Africa, and its bearing on their hydrocarbon potential. Transactions of the Geological Society of South Africa 79, $81-145$.

Ruckwied, K., Götz, A.E., Jones, P., 2014. Palynological records of the Permian Ecca Group (South Africa): Utilizing climatic icehouse-greenhouse signals for cross basin correlations. Palaeogeogr. Palaeoclimatol. Palaeoecol. 413, 167-172.

Santos, R.V., Souza, P.A., Alvarenga, C.J.S., Dantas, E.L., Pimentel, M.M., Oliveira, C.G. de, Araújo, L.M., 2006. Shrimp U-Pb zircon dating and palynology of bentonitic layers from the Permian Irati Formation, Paraná Basin, Brazil. Gondwana Res. 9, 456-463.

Santos, R.V., Dantas, E.L., Oliveira, C.G. de, Alvarenga, C.J.S., Anjos, C.W.D. dos, Guimarães, E.M., Oliveira, F.B., 2009. Geochemical and thermal effects of a basic sill on black shales and limestones of the Permian Irati Formation. J. S. Am. Earth Sci. 28, 14-24.

Schulz, H.-M., Linol, B., de Wit, M., Schuck, B., Schaepen, I., Wirth, R., 2018. Early diagenetic signals archived in black shales of the Dwyka and Lower Ecca Groups of the southern Karoo Basin (South Africa): Keys to the deglaciation history of Gondwana during the Early Permian, and its effect on potential shale gas storage. S. Afr. J. Geol. 121, 47-72.

Tankard, A., Welsink, H., Aukes, P., Newton, R., Stettler, E., 2009. Tectonic evolution of the Cape and Karoo basins of South Africa. Mar. Petrol. Geol. 26, 1379-1412.

Tyson, R.V., 1989. Late Jurassic palynofacies trends, Piper and Kimmeridge Clay Formations, UK onshore and offshore. In: Batten, D.J., Keen, M.C. (Eds.), Northwest European Micropalaeontology and Palynology. British Micropalaeontological Society Series, Ellis Horwood, Chichester, pp. 135-172.

Tyson, R.V., 1993. Palynofacies analysis. In: Jenkins, D.G. (Ed.), Applied Micropaleontology. Kluwer Academic Publishers, Dordrecht, pp. 153-191.

Tyson, R.V., 1995. Sedimentary Organic Matter: Organic Facies and Palynofacies. Chapman \& Hall, London, $615 \mathrm{pp}$.

Van Krevelen, D.W., 1993. Coal: Typology, Physics, Chemistry, Constitution. 3rd Edition, Elsevier, Amsterdam, 979 pp. 
Veevers, J.J., Cole, D.I., Cowan, E.J., 1994. Southern Africa: Karoo Basin and Cape Fold Belt. In: Veevers, J.J., Powell, C.McA. (Eds.), Permian-Triassic Pangean Basins and fold belts along the Panthalassan Margin of Gondwanaland. GSA Memoir 184, 223-279.

Ward, C.R, Li, Z., Gurba, L.W., 2008. Comparison of elemental composition of macerals determined by electron microprobe to whole-coal ultimate analysis data. Int. J. Coal Geol. 75, 157-65.

Wei, Q., Dai, S., Lefticariu, L., Costin, G., 2018. Electron probe microanalysis of major and trace elements in coals and their low-temperature ashes from the Wulantuga and Lincang Ge ore deposits, China. Fuel 215, 1-12.

\section{Tables}

Table 1: Modal composition and average size of particles in black shales from the Whitehill Formation, southern Karoo Basin.

Table 2A: Major and minor elements in black shale from borehole KZF-1 (southwestern Karoo Basin). Table 2B: Major and minor elements in black shale from borehole KWV-1 (southeastern Karoo Basin).

Table 3A: In situ EPMA major, minor and trace element analysis of the organic particles in black shale from borehole KZF-1 (in ppm, except C and O).

Table 3B: In situ EPMA major, minor and trace element analysis of the organic particles in black shale from borehole KWV-1 (in ppm, except C and O).

Table 4: Trace element composition of black shales (LA-ICP MS data), Whitehill Formation of the southern Karoo Basin.

\section{Figure captions}

Figure 1: Geological map of the Main Karoo Basin (based on Catuneanu et al., 1998) and location of studied boreholes (KZF-1, KWV-1), and also the SOEKOR borehole DP 1/78 and Ecca Pass section. Lithostratigraphic units of the Karoo Supergroup (Dwyka, Ecca, Beaufort, Stormberg, and Drakensberg groups) according to Johnson et al. $(1997,2006)$. Abbreviations used: Guad. = Guadalupian, Lop. = Lopingian (Lucas and Shen 2018). 
Figure 2: Palynofacies of the Whitehill Formation illustrated in the AOM-Phytoclast-Palynomorph plot (Tyson, 1989, 1993, 1995). Facies field II represents marginal, dysoxic-anoxic depositional environments, facies field IV shelf to basin transition with dysoxic-suboxic (IVa), and suboxic-anoxic (IVb) conditions, respectively. Facies field VII represents distal suboxic-anoxic basinal settings. Insert shows general proximal-distal and oxic-anoxic trends inferred from palynofacies data. Palynofacies of the studied Whitehill shales is dominated by phytoclasts and AOM (photograph, slide KZF-1/WH-3).

Figure 3: Backscattered electron (BSE) image (KZF-1 shales), showing mineral phases and organic particles characteristic of the massive shale type in the southwestern Karoo Basin. Abbreviations used: Ank - ankerite; Po - pyrrhotite; Qz - quartz; Ab - albite; Pl - plagioclase (oligoclase), Pyr - pyrite; OP organic particle.

Figure 4: Morphology and internal textures of organic particles (OP) in KZF-1 shales. Note the variability of shape and size (A-D), as well as the preservation of the organic texture (B, C, D).

Figure 5: Backscattered electron (BSE) image (KWV-1 shales), showing two laminae (Lamina 1 and 2) with different mineralogy and textures characteristic of the layered shale type in the southeastern Karoo Basin. Abbreviations used: Pl - plagioclase (andesine); Po - pyrrhotite; Qz - quartz; Ttn - titanite; Ilt - illite; OP - organic particle.

Figure 6: Morphology and distribution pattern of organic particles (OP) in KWV-1 shales. Note the deformed organic particles (A) and the mobilized, vein-like distribution of organic particles (B). No organic textures are preserved.

Figure 7: Geochemical plots suggesting clear mineralogical differences between the KZF-1 and KWV1 shales. a) $\mathrm{MgO} \#$ vs. $\left(\mathrm{Na}_{2} \mathrm{O}+\mathrm{CaO}\right)$ plot; b) $\left(\mathrm{Na}_{2} \mathrm{O}+\mathrm{CaO}\right)$ vs. $\mathrm{Al}_{2} \mathrm{O}_{3}$ plot. See text for interpretation.

Figure 8: Backscattered electron (BSE) images of different organic particles. OP1: particle with cellular texture (untransformed organic matter); OP2: texture-free organic particle; OP3: vein-like transformed and partially deformed/mobilized organic particle.

Figure 9: Carbon peak shift as a function of the maturation of organic particles. OP1, OP2 and OP3 represent the different organic particles illustrated in Figure 8. The Y-axis (counts per second) is not to scale. The X-axis is L-value, in millimetres (L-value is the JEOL measure of the distance between the sample and the analyzing crystal, hence the length of a segment in the Rawland circle of the WDS spectrometer, reflecting the position of different X-ray peaks). 
Figure 10: WDS quantitative mapping of a) the carbon content of particle OP1 (sample KZF-1); and b) of particle OP3 (sample KWV-1).

Figure 11: Trace element patterns of KZF-1 and KWV-1 shales relative to the MAG-1 standard.

Figure 12: $\mathrm{Th} v s . \mathrm{Al}_{2} \mathrm{O}_{3}$ (left) and Th vs. U (right) plots. 1: Upper Devonian Woodford shale, Permian Basin, West Texas (Harris et al., 2013); 2: black shale, and 3: silty black shale, both from the Early Cambrian Niutitang Formation, South China (Pi et al., 2013); 4: Permian Irati Formation, Brazil (Santos et al., 2009); 5: KZF-1 shales, 6: KWV-1 shales (this study).

Figure 13: Cr-Ni-Pb*10 (left) and U-Th-V/10 (right) diagram. 1: Upper Devonian Woodford shale, Permian Basin, West Texas (Harris et al., 2013); 2: black shale, and 3: silty black shale, both from the Early Cambrian Niutitang Formation, South China (Pi et al., 2013); 4: Permian Irati Formation, Brazil (Santos et al., 2009); 5: KZF-1 shales, 6: KWV-1 shales (this study); 7: Cambrian shales, China (Xu et al., 2012).

Figure 14: Mo vs. TOC diagram. 1: Upper Devonian Woodford shale, Permian Basin, West Texas (Harris et al., 2013); 2: black shale, and 3: silty black shale, both from the Early Cambrian Niutitang Formation, South China (Pi et al., 2013); 4: Permian Irati Formation, Brazil (Santos et al., 2009); 5: KZF-1 shales, 6: KWV-1 shales (this study); 7: Cambrian shales, China (Xu et al., 2012); 8: Permian Irati Formation, Paraná Basin, Brazil (Goldberg and Humayun, 2016). 


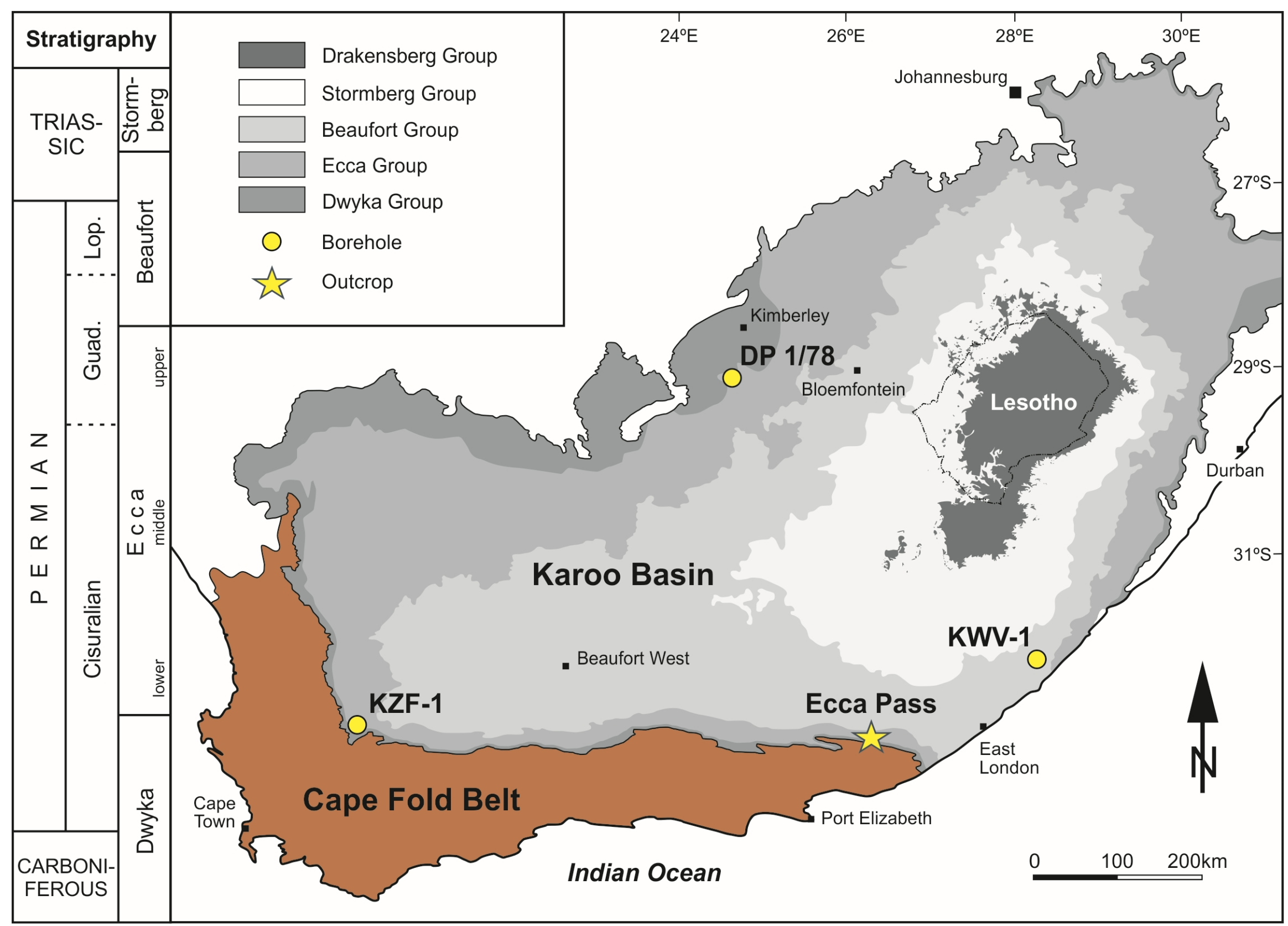



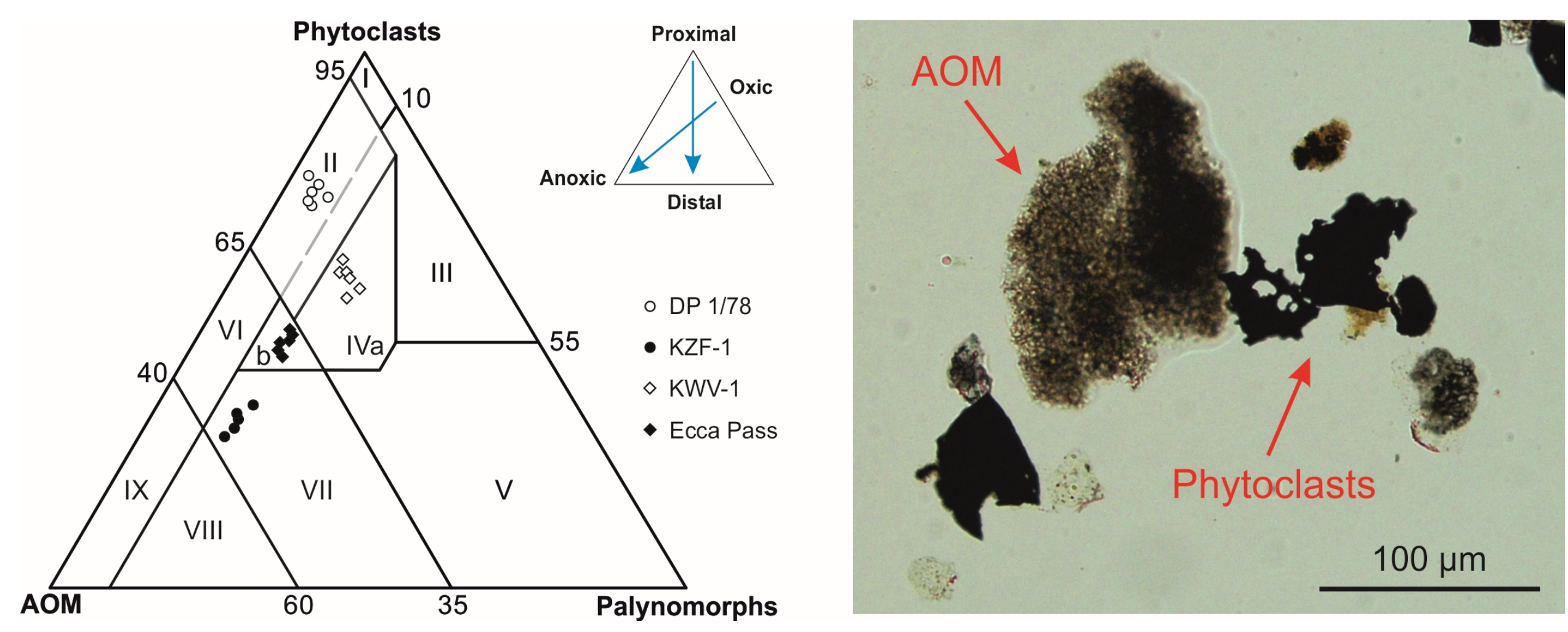


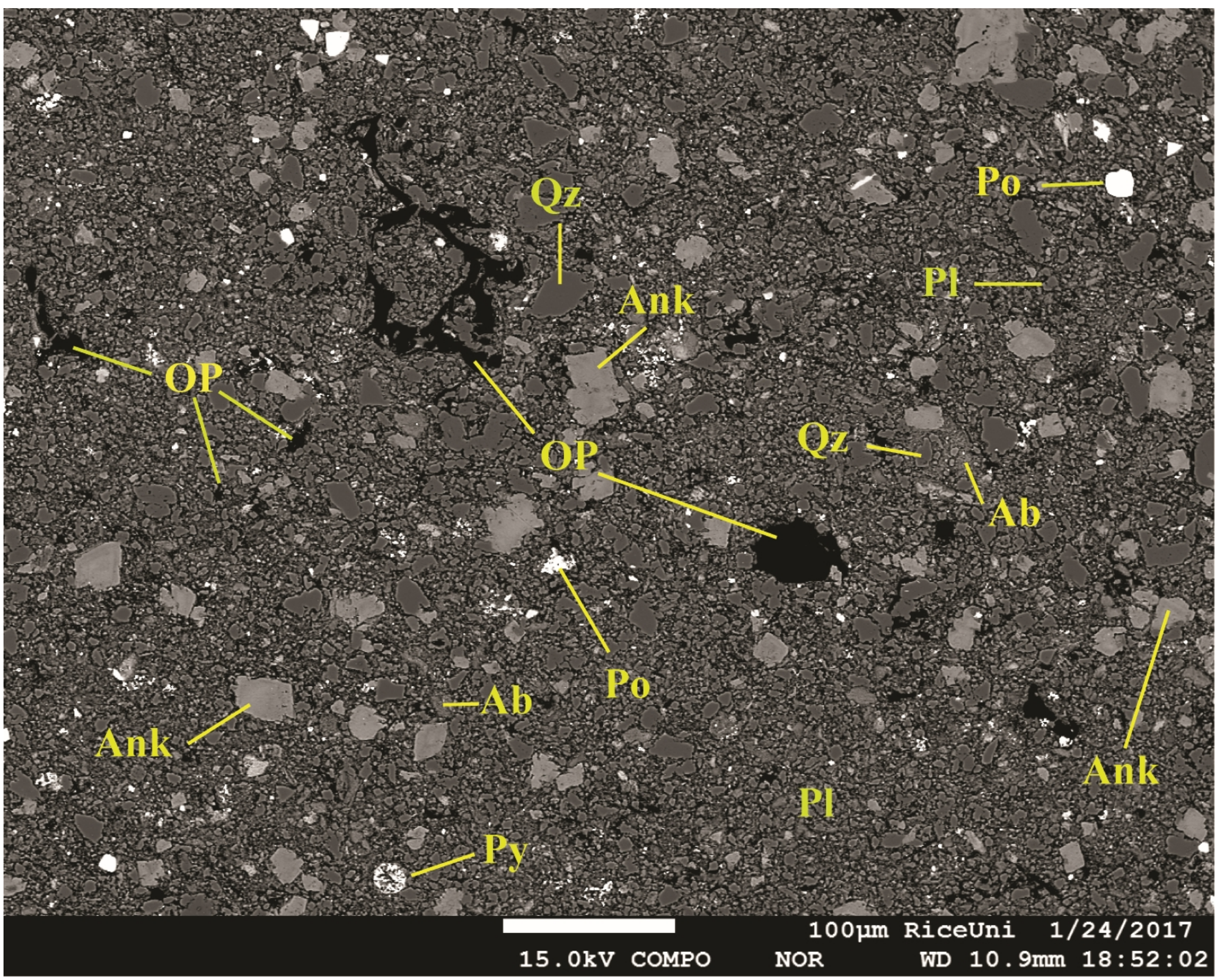



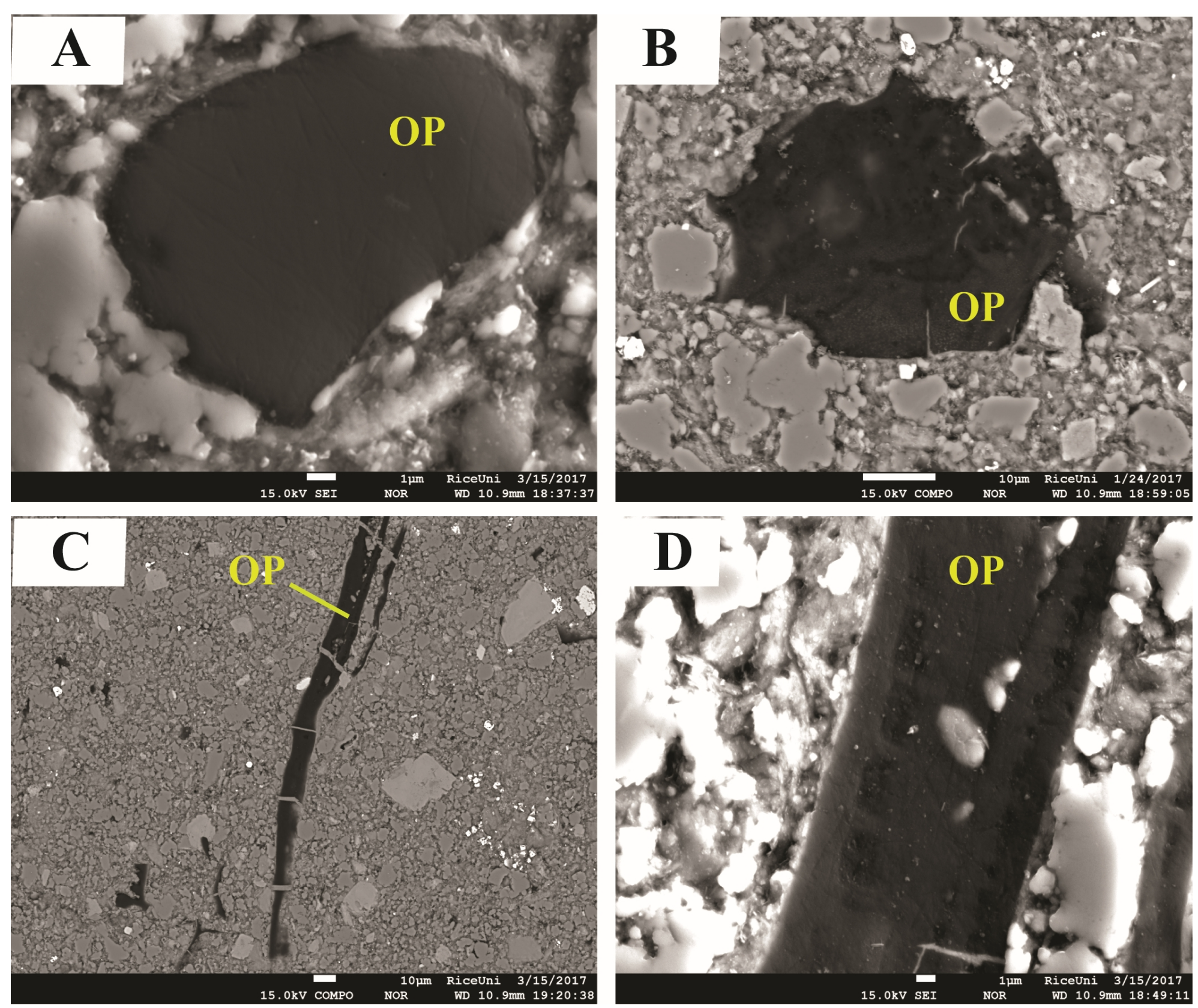


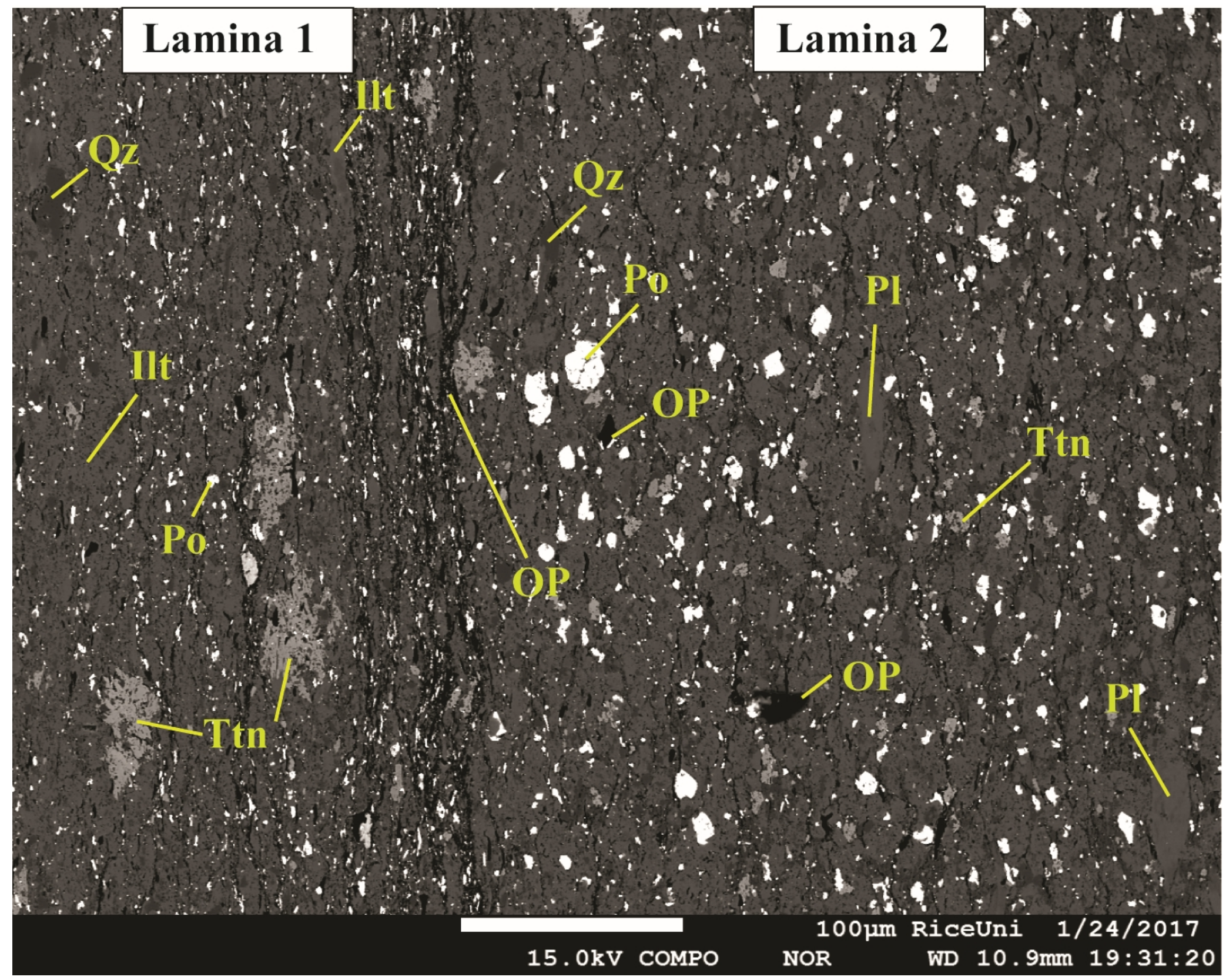



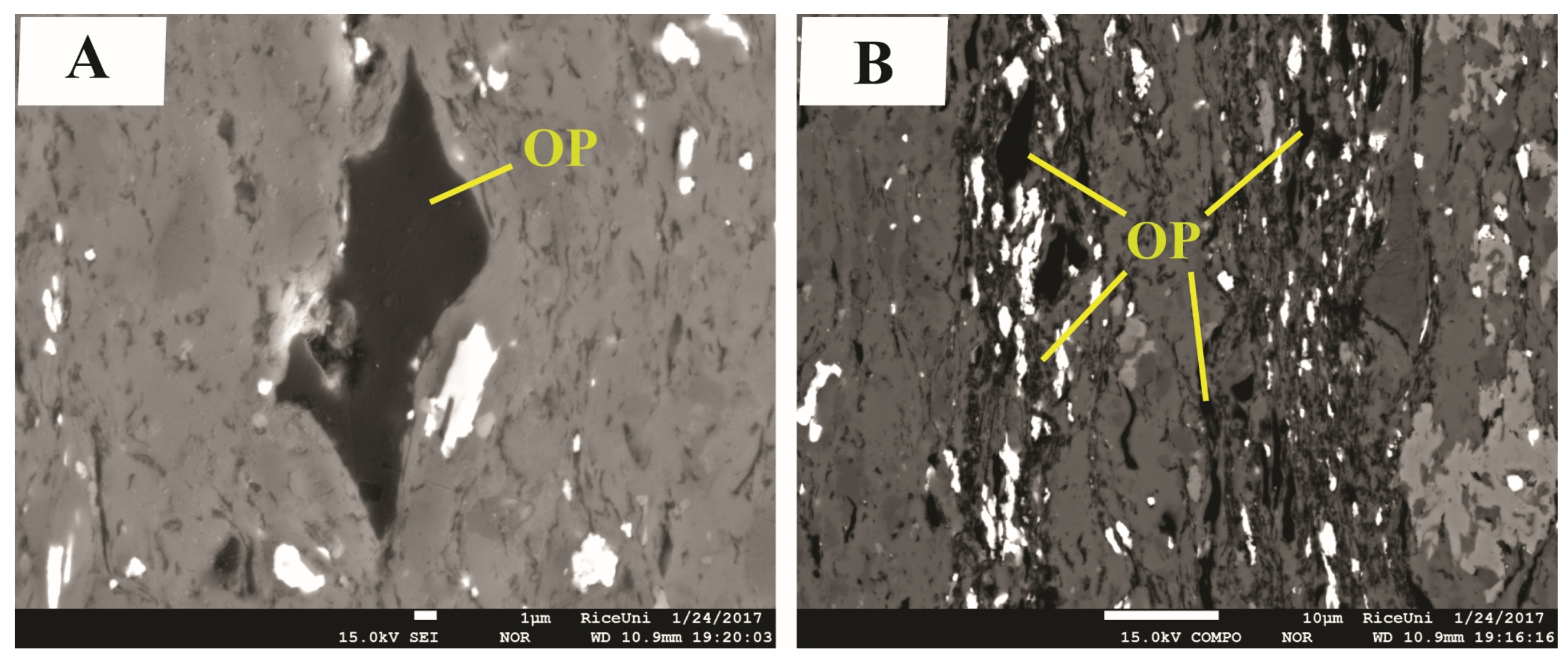


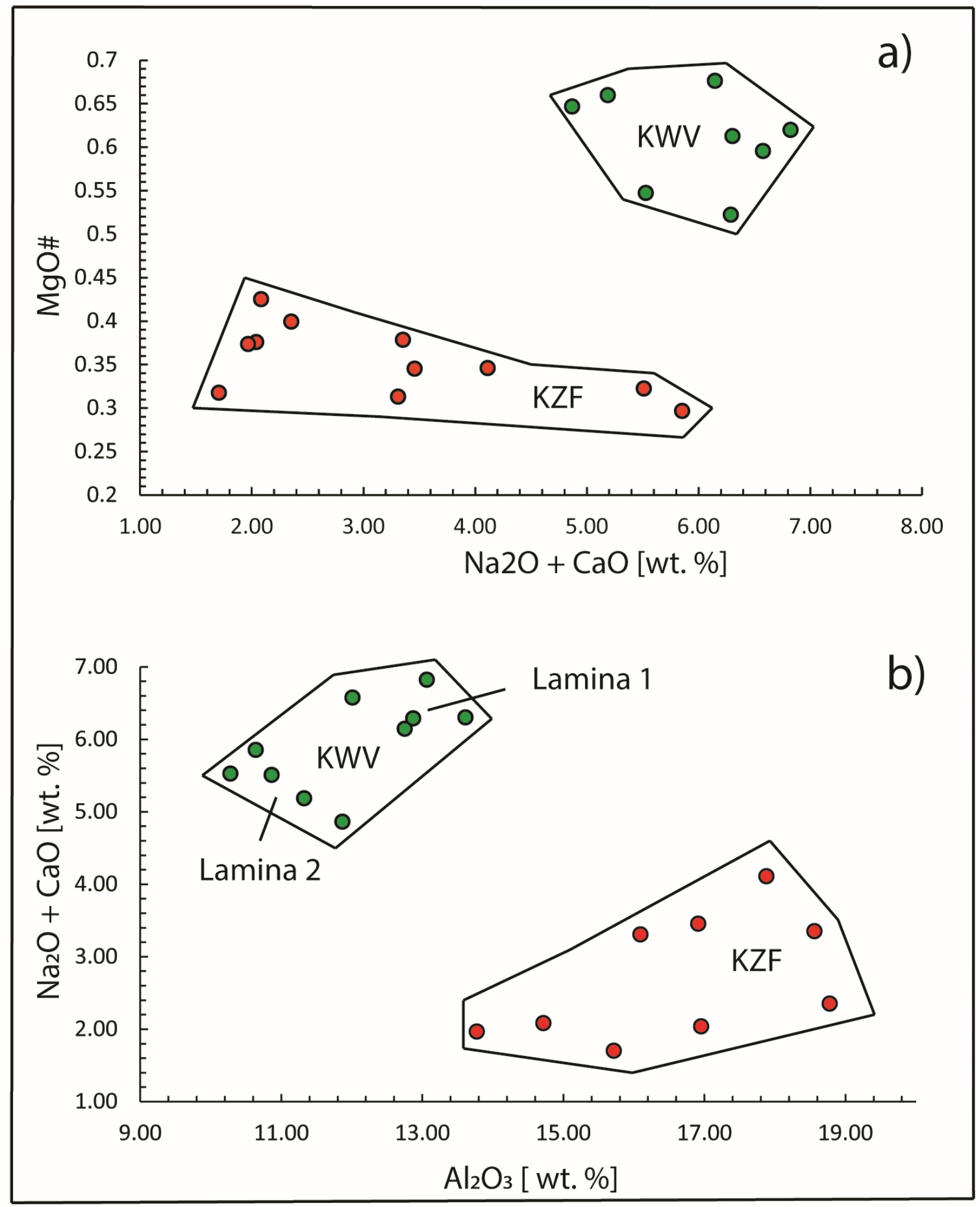



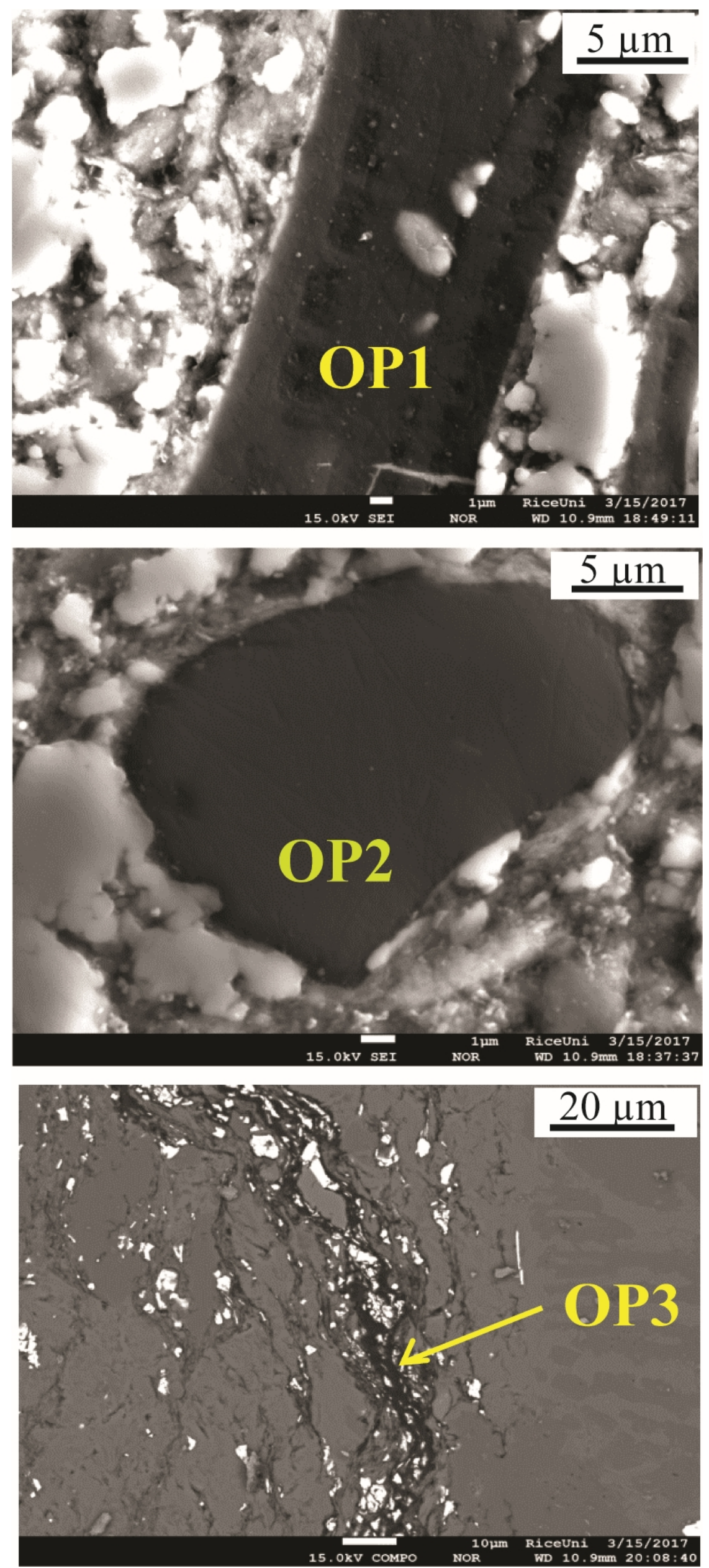


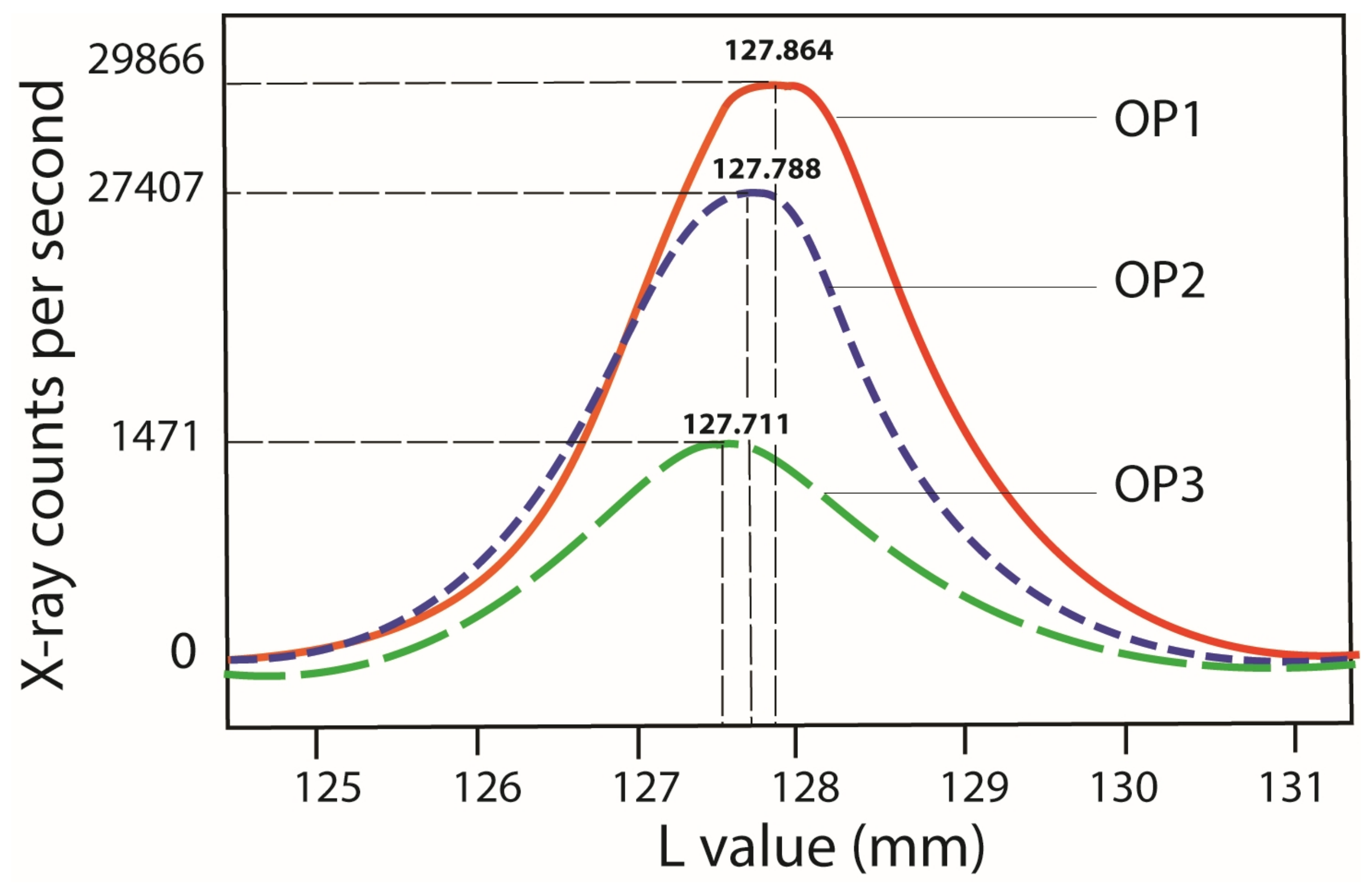




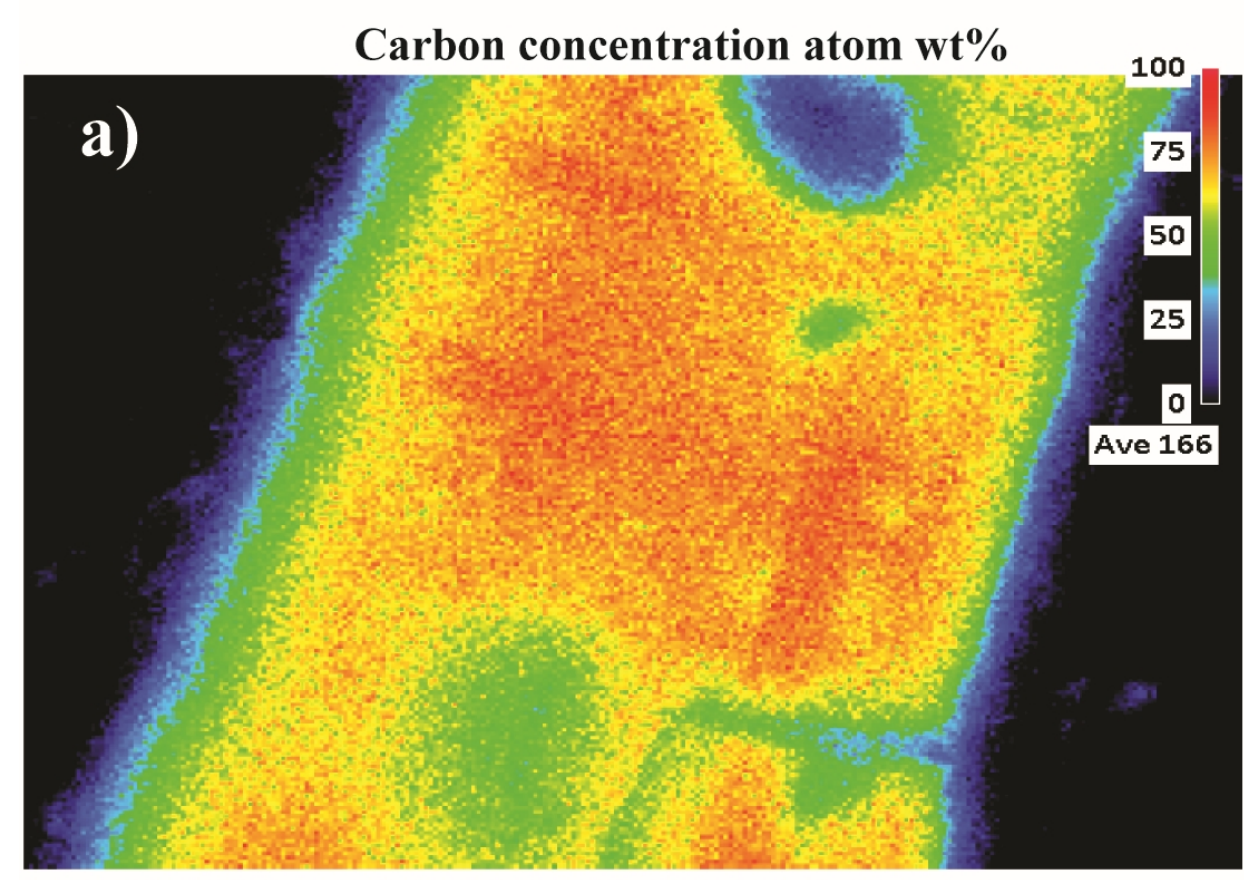

c 2 um

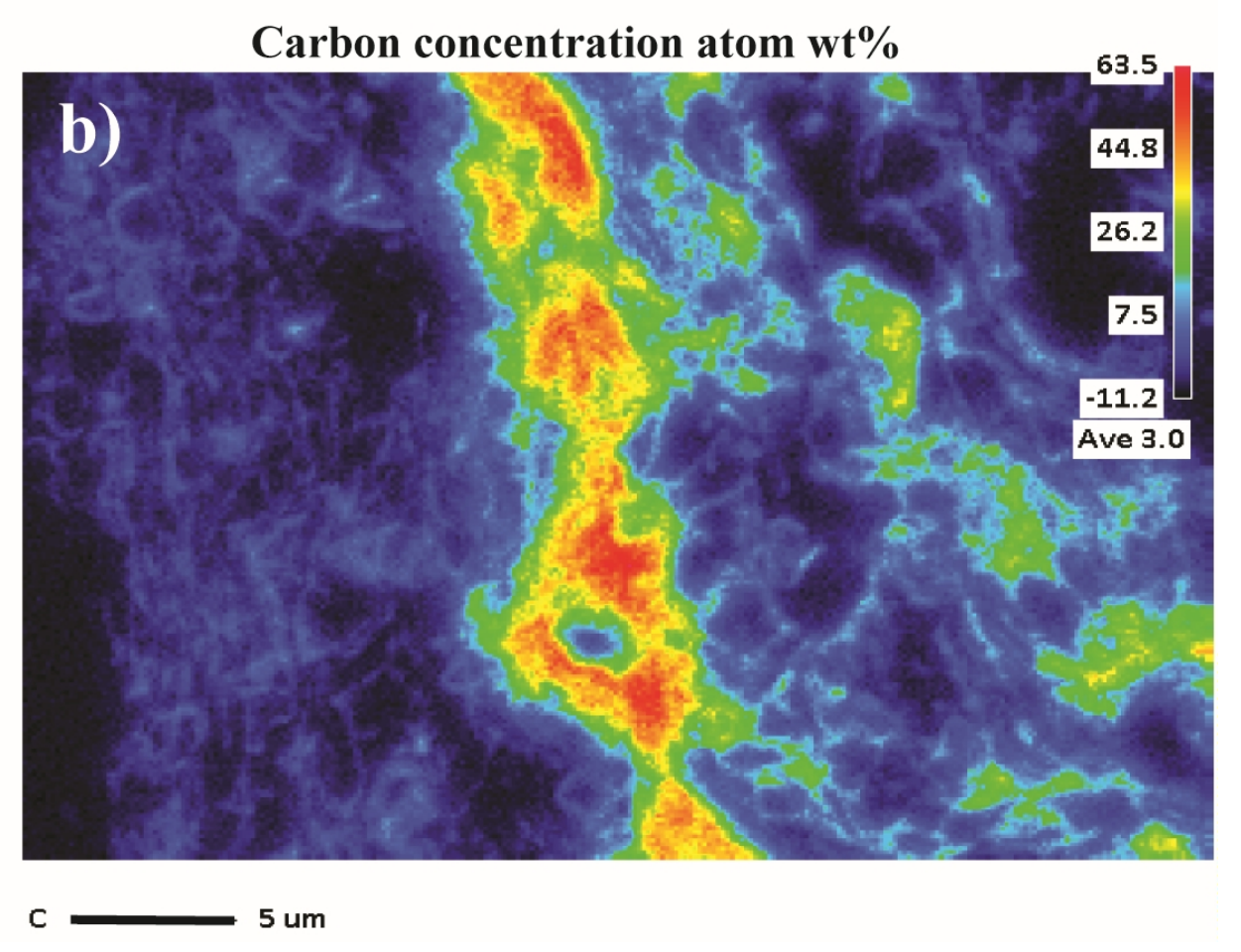




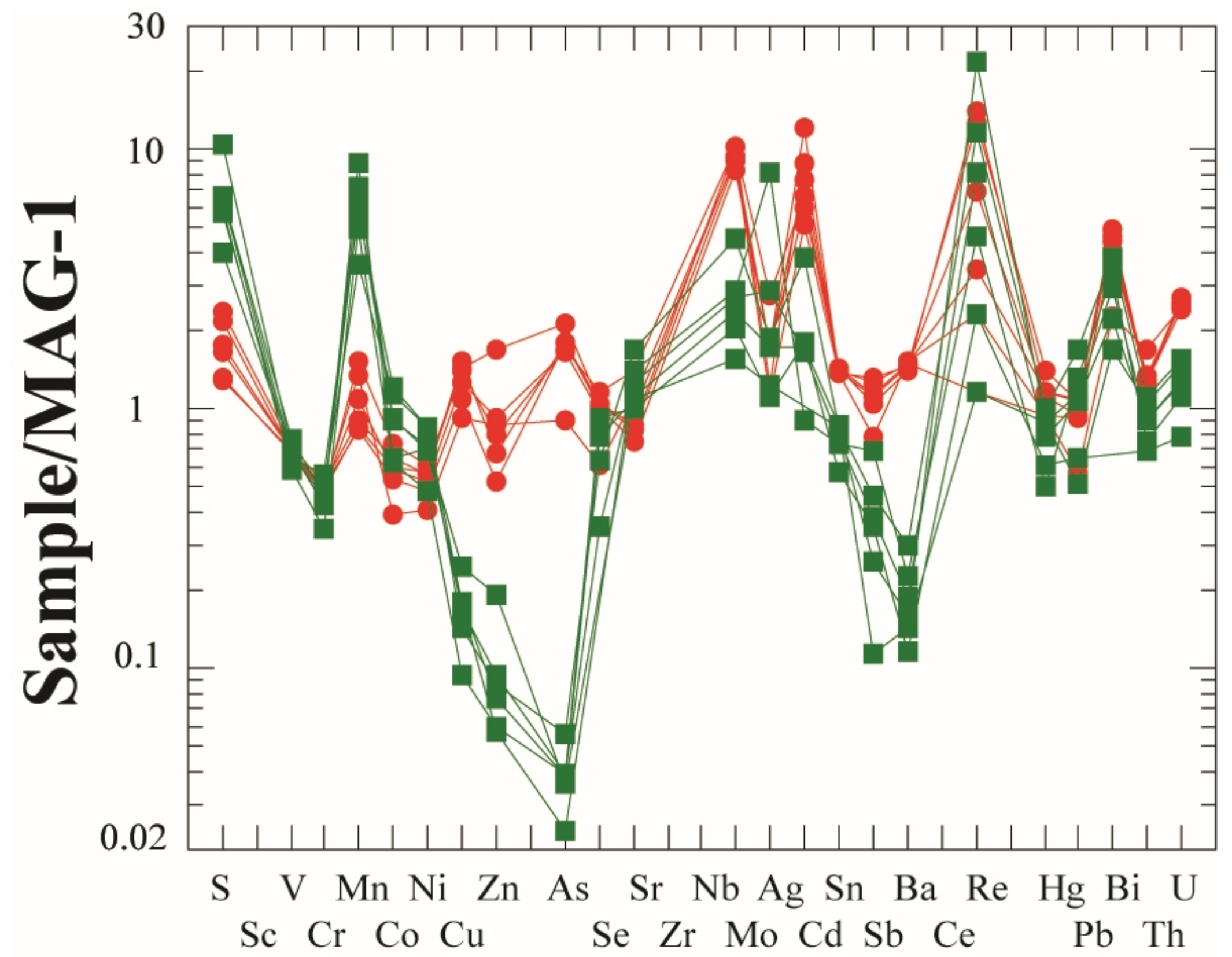



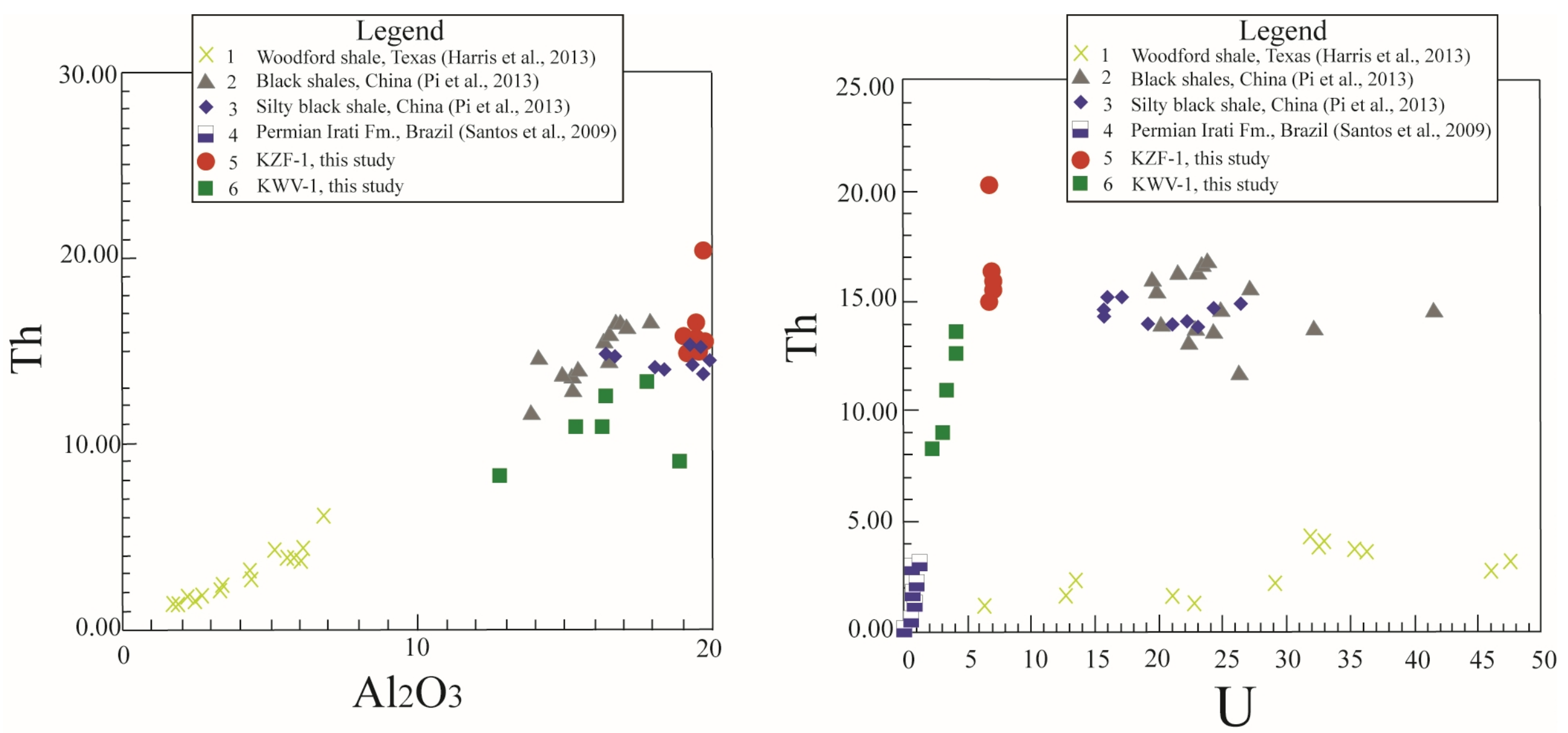


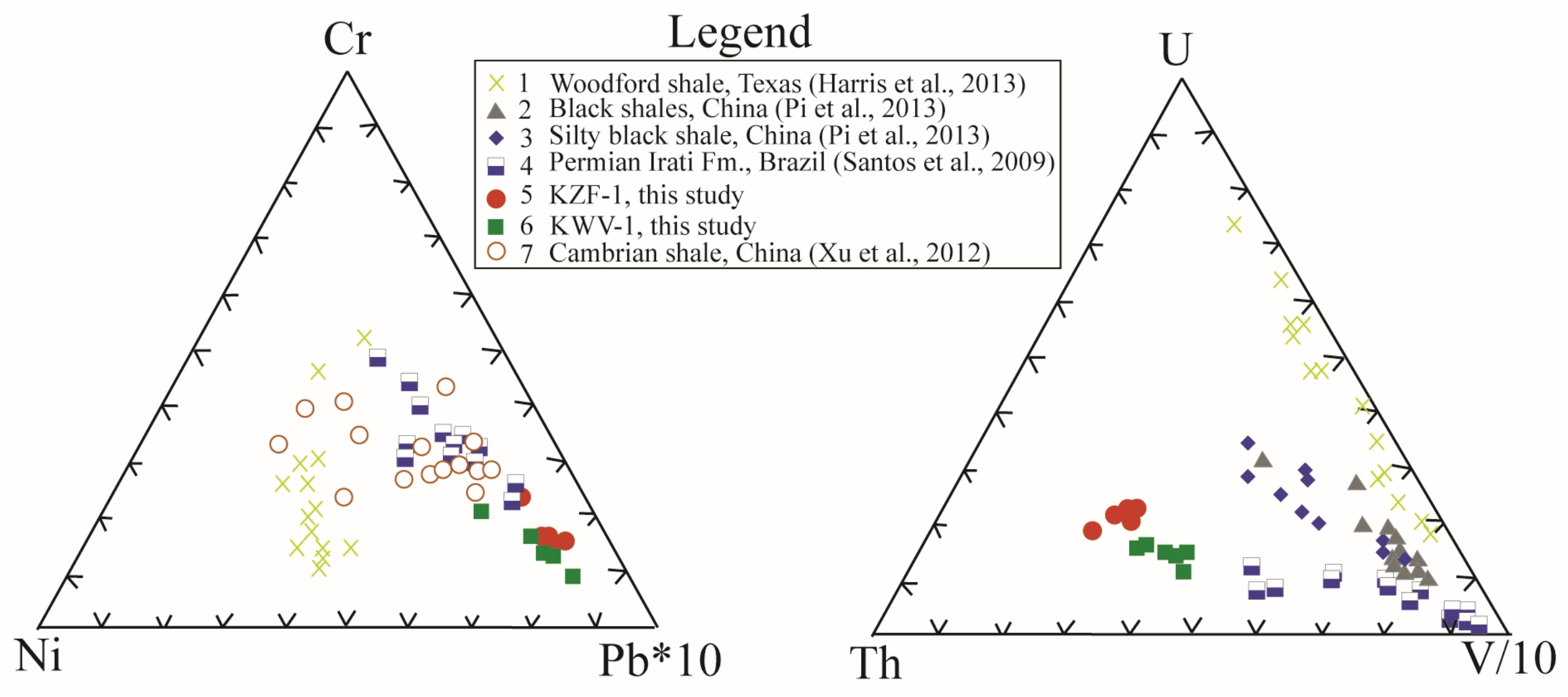




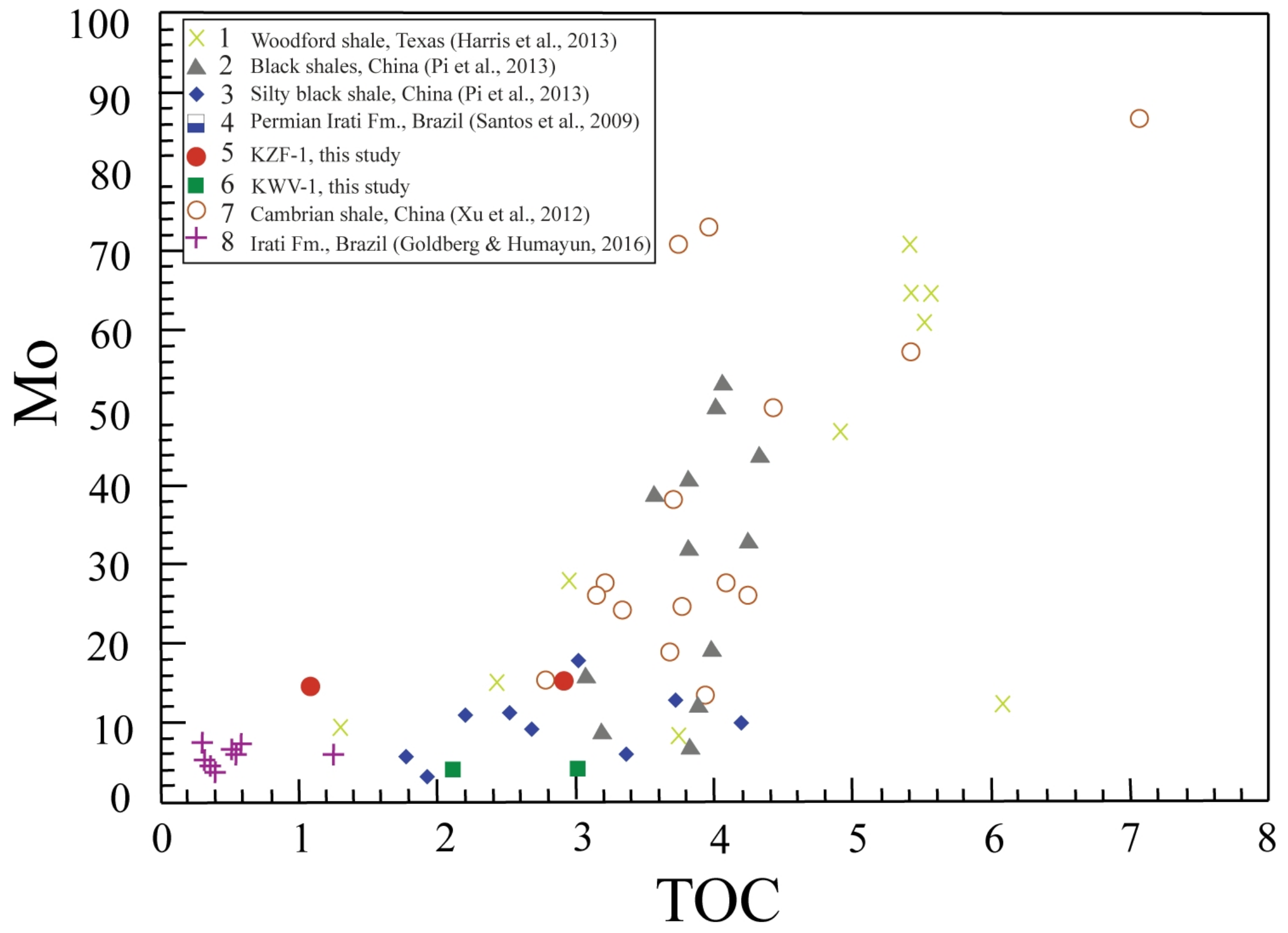


Table 1: Modal composition and average size of particles in black shales from the Whitehill Formation, southern Karoo Basin.

\begin{tabular}{|l|c|c|c|c|c|c|}
\hline \multicolumn{1}{|c|}{ Mineral/phase } & $\begin{array}{c}\text { KZF-1 } \\
(\mathrm{vol} \%)\end{array}$ & $\begin{array}{c}\text { Average } \\
\text { Size } \\
(\mu \mathrm{m})\end{array}$ & $\begin{array}{c}\text { KWV-1 } \\
\text { Lamina 1 } \\
(\mathrm{vol} \%)\end{array}$ & $\begin{array}{c}\text { Average } \\
\text { Size } \\
(\mu \mathrm{m})\end{array}$ & $\begin{array}{c}\text { KWV-1 } \\
\text { Lamina 2 } \\
(\mathrm{vol} \%)\end{array}$ & $\begin{array}{c}\text { Average } \\
\text { Size } \\
(\mu \mathrm{m})\end{array}$ \\
\hline Quartz & $19.8( \pm 4)$ & 15 & $3( \pm 0.5)$ & 5 & $11.8( \pm 1.85)$ & 5 \\
\hline Plag (oligoclase) & $37.4( \pm 4.5)$ & 8 & $11.5( \pm 2)$ & 8 & $75( \pm 4.75)$ & 10 \\
\hline Albite & $29.1( \pm 4.5)$ & 5 & - & - & - & - \\
\hline Carbonate $^{1}$ & $7.8( \pm 1.5)$ & 50 & - & - & - & - \\
\hline Sulfide $^{2}$ & $0.9( \pm 0.1)$ & 3 & $2( \pm 0.5)$ & 3 & $6( \pm 1.25)$ & 10 \\
\hline Titanite $(t t n)^{\text {Chlorite }}$ & 0 & 0 & $6( \pm 0.75)$ & 30 & $2( \pm 0.25)$ & 8 \\
\hline $\begin{array}{l}\text { Organic particles } \\
\text { (OP) }\end{array}$ & $0.9( \pm 0.25)$ & 20 & $0.5( \pm 0.1)$ & 2 & $0.2( \pm 0.05)$ & 3 \\
\hline Clay $^{3}$ & $4.1( \pm 0.35)$ & $<2$ & $77( \pm 6)$ & 2 & $1( \pm 0.25)$ & 1 \\
\hline Total & 100.0 & & 100.0 & & 100.0 & \\
\hline
\end{tabular}

${ }^{1}$ ankerite (ank) and minor calcite; Mn shows compositional zoning in ankerite;

${ }^{2}$ mostly pyrrhotite (po) and rare framboidal pyrite (pyr);

3 illite (ill). 
Table 2A: Major and minor elements in black shale from borehole KZF-1 (southwestern Karoo Basin)*

\begin{tabular}{cccccccccccccc}
\hline Analysis & $\mathrm{SiO} 2$ & $\mathrm{TiO} 2$ & $\mathrm{Al} 2 \mathrm{O} 3$ & $\mathrm{Cr} 2 \mathrm{O} 3$ & $\mathrm{FeO}$ & $\mathrm{MnO}$ & $\mathrm{MgO}$ & $\mathrm{CaO}$ & $\mathrm{Na} 2 \mathrm{O}$ & $\mathrm{K} 2 \mathrm{O}$ & $\mathrm{P} 2 \mathrm{O} 5$ & $\mathrm{~S} * *$ & Total \\
\hline KZF-1_1 & 61.37 & 0.17 & 18.78 & $\mathrm{bd}$ & 2.15 & 0.04 & 1.43 & 0.32 & 2.03 & 3.40 & 0.15 & 0.14 & 89.96 \\
KZF-1_2 & 64.50 & 0.52 & 16.91 & 0.03 & 2.24 & 0.00 & 1.18 & 0.38 & 3.08 & 2.48 & 0.08 & 0.58 & 91.97 \\
KZF-1_3 & 70.25 & 0.22 & 14.72 & bd & 1.42 & 0.01 & 1.05 & 0.29 & 1.79 & 2.84 & 0.06 & 0.05 & 92.70 \\
KZF-1_4 & 60.33 & 0.31 & 18.56 & bd & 2.23 & 0.02 & 1.36 & 0.25 & 3.11 & 3.04 & 0.04 & 0.19 & 89.44 \\
KZF-1_5 & 63.53 & 0.51 & 16.09 & 0.01 & 2.38 & bd & 1.09 & 0.31 & 3.01 & 3.09 & na & na & 90.01 \\
KZF-1_6 & 64.11 & 0.39 & 16.96 & bd & 3.00 & 0.02 & 1.81 & 0.22 & 1.82 & 3.02 & 0.03 & 0.06 & 91.45 \\
KZF-1_7 & 60.51 & 0.19 & 17.88 & 0.02 & 2.11 & 0.02 & 1.12 & 0.81 & 3.30 & 3.10 & 0.13 & 0.66 & 89.85 \\
KZF-1_8 & 68.71 & 0.24 & 13.77 & 0.05 & 1.62 & 0.00 & 0.96 & 0.26 & 1.71 & 3.48 & na & na & 90.80 \\
KZF-1_9 & 63.99 & 0.35 & 15.72 & 0.02 & 3.25 & 0.00 & 1.51 & 0.15 & 1.55 & 3.74 & na & na & 90.28 \\
\hline Average & $\mathbf{6 4 . 1 4}$ & $\mathbf{0 . 3 2}$ & $\mathbf{1 6 . 6 0}$ & $\mathbf{0 . 0 3}$ & $\mathbf{2 . 2 7}$ & $\mathbf{0 . 0 1}$ & $\mathbf{1 . 2 8}$ & $\mathbf{0 . 3 3}$ & $\mathbf{2 . 3 8}$ & $\mathbf{3 . 1 3}$ & $\mathbf{0 . 0 8}$ & $\mathbf{0 . 2 8}$ & $\mathbf{9 0 . 8 5}$ \\
St Dev & $\mathbf{3 . 4 3}$ & $\mathbf{0 . 1 3}$ & $\mathbf{1 . 7 0}$ & $\mathbf{0 . 0 2}$ & $\mathbf{0 . 5 8}$ & $\mathbf{0 . 0 1}$ & $\mathbf{0 . 2 7}$ & $\mathbf{0 . 1 9}$ & $\mathbf{0 . 7 2}$ & $\mathbf{0 . 3 7}$ & $\mathbf{0 . 0 5}$ & $\mathbf{0 . 2 7}$ & $\mathbf{1 . 1 0}$ \\
\hline
\end{tabular}

* by EPMA, analysis with beam size of 60 micrometre (LOI not analyzed);

**in atom wt.\%; bd: below detection limit; na: not analyzed.

Table 2B: Major and minor elements in black shale from borehole KWV-1 (southeastern Karoo Basin)*

\begin{tabular}{cccccccccccccc}
\hline Analysis & $\mathrm{SiO} 2$ & $\mathrm{TiO} 2$ & $\mathrm{Al} 2 \mathrm{O} 3$ & $\mathrm{Cr} 2 \mathrm{O} 3$ & $\mathrm{FeO}$ & $\mathrm{MnO}$ & $\mathrm{MgO}$ & $\mathrm{CaO}$ & $\mathrm{Na} 2 \mathrm{O}$ & $\mathrm{K} 2 \mathrm{O}$ & $\mathrm{P} 2 \mathrm{O} 5$ & $\mathrm{~S} * *$ & Total \\
\hline KWV-1_1 & 64.57 & 0.21 & 10.86 & bd & 5.92 & 0.32 & 2.82 & 5.27 & 0.24 & 0.53 & 0.26 & 3.37 & 94.37 \\
KWV-1_2 & 66.52 & 0.51 & 13.06 & bd & 1.61 & 0.30 & 2.62 & 6.51 & 0.31 & 0.49 & 0.22 & 0.51 & 92.67 \\
KWV-1_3 & 68.48 & 0.38 & 10.64 & bd & 4.03 & 0.24 & 1.70 & 5.49 & 0.37 & 0.29 & 0.17 & 2.32 & 94.10 \\
KWV-1_4 & 61.66 & 0.23 & 13.61 & 0.01 & 3.02 & 0.48 & 4.78 & 5.94 & 0.37 & 0.62 & 0.12 & 0.96 & 91.77 \\
KWV-1_5 & 61.34 & 0.20 & 11.87 & 0.01 & 3.65 & 0.89 & 6.69 & 4.58 & 0.29 & 0.62 & 0.59 & 0.88 & 91.59 \\
KWV-1_6 & 65.34 & 0.22 & 11.33 & 0.03 & 2.49 & 0.51 & 4.82 & 4.87 & 0.31 & 0.84 & 0.42 & 0.50 & 91.66 \\
KWV-1_7 & 65.09 & 0.12 & 10.28 & 0.01 & 3.66 & 0.63 & 4.42 & 5.19 & 0.34 & 0.69 & 0.17 & 1.56 & 92.15 \\
KWV-1_8 & 64.57 & 0.18 & 12.75 & 0.02 & 2.06 & 0.42 & 4.30 & 5.78 & 0.37 & 0.59 & 0.32 & 0.41 & 91.75 \\
KWV-1_9 & 68.12 & 0.29 & 12.01 & 0.01 & 1.75 & 0.36 & 2.57 & 6.22 & 0.36 & 0.68 & 0.12 & 0.69 & 93.17 \\
KWV-1_10 & 62.89 & 0.20 & 12.87 & 0.01 & 3.33 & 0.44 & 3.65 & 5.98 & 0.31 & 0.49 & 0.20 & 1.55 & 91.91 \\
\hline Average & $\mathbf{6 4 . 8 6}$ & $\mathbf{0 . 2 5}$ & $\mathbf{1 1 . 9 3}$ & $\mathbf{0 . 0 1}$ & $\mathbf{3 . 1 5}$ & $\mathbf{0 . 4 6}$ & $\mathbf{3 . 8 4}$ & $\mathbf{5 . 5 8}$ & $\mathbf{0 . 3 3}$ & $\mathbf{0 . 5 8}$ & $\mathbf{0 . 2 6}$ & $\mathbf{1 . 2 7}$ & $\mathbf{9 2 . 5 2}$ \\
St Dev & $\mathbf{2 . 4 4}$ & $\mathbf{0 . 1 1}$ & $\mathbf{1 . 1 3}$ & $\mathbf{0 . 0 1}$ & $\mathbf{1 . 2 9}$ & $\mathbf{0 . 1 9}$ & $\mathbf{1 . 4 6}$ & $\mathbf{0 . 6 1}$ & $\mathbf{0 . 0 4}$ & $\mathbf{0 . 1 5}$ & $\mathbf{0 . 1 5}$ & $\mathbf{0 . 9 5}$ & $\mathbf{1 . 0 3}$ \\
\hline
\end{tabular}

* by EPMA, analysis with beam size of 60 micrometre (LOI not analyzed);

$* *_{\text {in }}$ atom wt. $\%$; bd: below detection limit. 
Table 3A: In situ EPMA major, minor and trace element analysis of the organic particles black shale from borehole KZF-1 (in ppm, except C and O)*

\begin{tabular}{|c|c|c|c|c|c|c|c|c|c|c|c|c|c|c|c|c|c|c|}
\hline Analysis & $\mathrm{C}^{* *}$ & $\mathrm{O} * *$ & $\mathrm{Si}$ & $\mathrm{Ti}$ & $\mathrm{Al}$ & V & $\mathrm{Fe}$ & $\mathrm{Mn}$ & $\mathrm{Mg}$ & $\mathrm{Ca}$ & $\mathrm{Na}$ & $\mathrm{K}$ & $\mathrm{N}$ & $\mathrm{S}$ & $\mathrm{Ge}$ & As & $\mathrm{U}$ & W \\
\hline KZF-1_OP1_1 & 87.69 & 3.67 & 5.8 & 0.0 & 1.7 & 0.0 & 22.1 & 0.0 & 8.3 & 10.5 & 1.3 & 8.7 & 587.0 & 141.4 & 4.7 & bd & bd & 0.9 \\
\hline KZF-1_OP1_2 & 88.40 & 3.22 & 160.1 & 6.2 & 97.5 & 0.0 & 21.2 & 9.0 & 3.7 & 8.4 & 3.5 & 41.2 & 626.0 & 144.2 & 1.5 & bd & bd & $\mathrm{bd}$ \\
\hline KZF-1_OP2_1 & 88.15 & 2.87 & 419 & 8.9 & 281.6 & 0.0 & 29.1 & 0.0 & 9.2 & 27.2 & 7.2 & 50.2 & 525.2 & 115.1 & bd & 2.0 & bd & bd \\
\hline KZF-1_OP2_2 & 88.06 & 1.83 & 26.7 & 0.0 & 203.9 & 1.9 & 30.8 & 1.4 & 17.1 & 30.4 & 13.2 & 15.2 & 517.3 & 119.5 & 0.2 & bd & bd & $\mathrm{bd}$ \\
\hline KZF-1_OP2_3 & 87.34 & 2.06 & 109.4 & 0.0 & 216.8 & 6.9 & 46.7 & 0.0 & 15.0 & 32.2 & 8.8 & 14.7 & 450.2 & 116.5 & 0.0 & bd & bd & $\mathrm{bd}$ \\
\hline KZF-1_OP3_1 & 87.51 & 2.29 & 26.4 & 0.0 & 15.1 & 6.5 & 15.6 & 0.0 & 0.0 & 4.9 & 17.0 & 7.5 & 613.0 & 352.4 & 5.5 & bd & bd & 0.7 \\
\hline KZF-1_OP3_2 & 85.17 & 2.88 & 97.2 & 1.4 & 73.0 & 6.5 & 51.4 & 13.7 & 12.1 & 1.3 & 11.4 & 17.0 & 512.0 & 358.2 & bd & bd & bd & bd \\
\hline KZF-1_OP3_3 & 87.08 & 2.78 & 197.1 & 10.3 & 61.4 & 5.3 & 35.8 & 0.0 & 0.0 & 3.2 & 12.9 & 16.4 & 638.0 & 363.4 & bd & 0.2 & bd & $\mathrm{bd}$ \\
\hline KZF-1_OP4_1 & 88.13 & 3.74 & 540 & 4.4 & 190.0 & 0.0 & 77.5 & 5.0 & 67.6 & 10.8 & 29.0 & 342.8 & 540.0 & 349.5 & bd & bd & bd & bd \\
\hline KZF-1_OP4_2 & 88.33 & 4.54 & 770 & 16.8 & 10.0 & 0.0 & 131.4 & 0.0 & 98.0 & 6.8 & 264.0 & 395.8 & 634.9 & 314.1 & $\mathrm{bd}$ & bd & bd & bd \\
\hline KZF-1_OP4_3 & 88.15 & 3.09 & 1070 & 0.0 & 980.0 & 6.4 & 101.0 & 0.0 & 41.8 & 24.0 & 1010.0 & 167.1 & 562.0 & 245.9 & $\mathrm{bd}$ & bd & bd & bd \\
\hline KZF-1_OP5_1 & 89.28 & 3.88 & 520 & 25.7 & 880.3 & 0.0 & 148.0 & 0.0 & 106.4 & 15.5 & 116.8 & 145.5 & 649.1 & 328.4 & bd & bd & bd & bd \\
\hline KZF-1_OP5_2 & 89.77 & 5.19 & 210 & 9.3 & 630.0 & 0.0 & 266.3 & 0.0 & 139.3 & 11.3 & 244.7 & 160.7 & 626.7 & 305.8 & bd & bd & bd & $\mathrm{bd}$ \\
\hline KZF-1_OP5_3 & 87.97 & 5.80 & 860 & 29.4 & 980.0 & 1.1 & 683.1 & 0.0 & 337.2 & 13.5 & 172.3 & 225.6 & 565.6 & 281.7 & 7.3 & bd & bd & bd \\
\hline Average & 87.93 & 3.42 & 358.0 & 8.0 & 330.1 & 2.5 & 118.6 & 2.1 & 61.1 & 14.3 & 136.6 & 114.9 & 574.8 & 252.6 & 3.2 & 1.1 & - & 0.8 \\
\hline St Dev & 1.06 & 1.15 & 345.6 & 9.8 & 371.1 & 3.0 & 176.5 & 4.3 & 91.5 & 10.2 & 268.0 & 130.3 & 60.0 & 102.0 & 3.0 & 1.3 & - & 0.1 \\
\hline
\end{tabular}

Table 3B: In situ EPMA major, minor and trace element analysis of the organic particles in black shale from borehole KWV-1 (in ppm, except C and O)*

\begin{tabular}{|c|c|c|c|c|c|c|c|c|c|c|c|c|c|c|c|c|c|c|}
\hline Analysis & $\mathrm{C}^{* *}$ & $\mathrm{O}^{* *}$ & $\mathrm{Si}$ & $\mathrm{Ti}$ & $\mathrm{Al}$ & V & $\mathrm{Fe}$ & $\mathrm{Mn}$ & $\mathrm{Mg}$ & $\mathrm{Ca}$ & $\mathrm{Na}$ & $\mathrm{K}$ & $\mathrm{N}$ & $\mathrm{S}$ & $\mathrm{Ge}$ & As & $\mathrm{U}$ & W \\
\hline KWV-1_OP1_1 & 87.36 & 3.02 & 970.0 & 2.9 & 776.7 & 0.0 & 1130.0 & 17.8 & 465.6 & 351.3 & 223.9 & 242.9 & 595.0 & 4200.0 & 1.3 & bd & bd & bd \\
\hline KWV-1_OP1_2 & 88.26 & 6.51 & 630.0 & 0.0 & 728.9 & 9.6 & 350.0 & 10.9 & 525.8 & 452.2 & 251.2 & 143.5 & 629.0 & 1500.0 & bd & bd & $\mathrm{bd}$ & $\mathrm{bd}$ \\
\hline KWV-1_OP2_1 & 88.85 & 3.38 & 400.0 & 6.2 & 533.9 & 6.6 & 474.0 & 40.3 & 518.1 & 351.6 & 106.2 & 108.3 & 564.0 & 3790.0 & bd & bd & $\mathrm{bd}$ & $\mathrm{bd}$ \\
\hline KWV-1_OP2_2 & 89.79 & 5.88 & 1000.0 & 13.2 & 993.1 & 0.0 & 580.0 & 94.1 & 1070.0 & 366.2 & 103.5 & 132.5 & 502.0 & 1310.0 & bd & bd & $\mathrm{bd}$ & $\mathrm{bd}$ \\
\hline KWV-1_OP2_3 & 87.85 & 2.22 & 940.0 & 10.3 & 714.5 & 4.7 & 830.0 & 4.9 & 560.2 & 467.0 & 121.1 & 144.9 & 614.0 & 1700.0 & bd & bd & bd & bd \\
\hline KWV-1_OP3_1 & 88.86 & 5.18 & 870.0 & 1.2 & 740.0 & 0.0 & 1850.0 & 20.4 & 473.8 & 412.6 & 339.1 & 179.8 & 518.0 & 1070.0 & $\mathrm{bd}$ & bd & bd & bd \\
\hline KWV-1_OP3_2 & 87.30 & 5.81 & 40.0 & 8.8 & 914.0 & 0.0 & 1620.0 & 19.0 & 467.4 & 347.6 & 183.8 & 249.8 & 647.0 & 1560.0 & bd & bd & $\mathrm{bd}$ & bd \\
\hline KWV-1_OP3_3 & 88.01 & 4.92 & 220.0 & 4.6 & 933.9 & 6.6 & 980.0 & 17.4 & 482.9 & 349.9 & 164.9 & 257.1 & 523.0 & 1160.0 & 0.0 & bd & bd & $\mathrm{bd}$ \\
\hline Average & 88.29 & 4.62 & 633.8 & 5.9 & 791.9 & 3.4 & 976.8 & 28.1 & 570.5 & 387.3 & 186.7 & 182.4 & 574.0 & 2036.3 & 0.7 & $b d$ & - & - \\
\hline St Dev & 0.85 & 1.55 & 373.2 & 4.6 & 148.8 & 3.9 & 537.8 & 28.5 & 204.6 & 49.6 & 81.9 & 59.4 & 55.3 & 1231.4 & 0.9 & $b d$ & - & - \\
\hline
\end{tabular}

${ }^{*}$ See Methods and analytical conditions; ${ }^{* *} \mathrm{C}$ and $\mathrm{O}$ are given in wt\% and were analyzed as major elements with different analytical conditions; bd: below detection limit. 
Table 4: Trace element composition of black shales (LA-ICP MS data), Whitehill Formation of the southern Karoo Basin.

\begin{tabular}{|c|c|c|c|c|c|c|c|c|c|c|c|c|c|c|c|c|}
\hline & KZF1_1 & KZF1_2 & KZF1_3 & KZF1_4 & $\mathrm{KZF1 \_ 5}$ & KZF1_6 & $\begin{array}{r}\text { Average } \\
\text { KZF1 } \\
\end{array}$ & $\begin{array}{r}\text { St Dev } \\
\text { KZF1 } \\
\end{array}$ & KWV1_1 & KWV1_2 & KWV1_3 & KWV1_4 & KWV1_5 & KWV1_6 & $\begin{array}{r}\text { Average } \\
\text { KWV1 } \\
\end{array}$ & $\begin{array}{r}\text { St Dev } \\
\text { KWV1 } \\
\end{array}$ \\
\hline $\mathrm{Na}$ & 2.1 & 1.9 & 2.1 & 2.1 & 2.0 & 3.9 & 2.3 & 0.8 & 0.2 & 0.2 & 0.2 & 0.3 & 0.1 & 4.9 & 1.0 & 1.9 \\
\hline $\mathrm{Mg}$ & 2.0 & 1.9 & 2.6 & 3.0 & 2.0 & 2.8 & 2.4 & 0.5 & 4.2 & 6.1 & 5.1 & 2.7 & 3.3 & 2.7 & 4.0 & 1.4 \\
\hline $\mathrm{Al}$ & 19.6 & 19.0 & 19.7 & 19.8 & 19.3 & 18.8 & 19.4 & 0.4 & 18.9 & 16.4 & 15.3 & 17.8 & 12.7 & 19.1 & 16.7 & 2.4 \\
\hline $\mathrm{Si}$ & 59.5 & 59.5 & 59.5 & 59.5 & 59.5 & 50.4 & 58.0 & 3.7 & 64.9 & 64.9 & 64.9 & 64.9 & 64.9 & 50.4 & 62.5 & 5.9 \\
\hline $\mathrm{P}$ & 0.1 & 0.1 & 0.1 & 0.2 & 0.1 & 0.2 & 0.1 & 0.0 & 0.2 & 0.3 & 0.2 & 0.3 & 0.2 & 0.2 & 0.2 & 0.1 \\
\hline $\mathrm{S}$ & 9217.5 & 6386.5 & 5040.5 & 8493.3 & 5064.1 & 5659.1 & 6643.5 & 1797.0 & 22001.3 & 15347.3 & 25654.1 & 40726.0 & 22880.0 & 4320.7 & 21821.6 & 12011.8 \\
\hline $\mathrm{K}$ & 3.3 & 3.2 & 3.3 & 3.3 & 3.3 & 3.9 & 3.4 & 0.2 & 1.2 & 0.9 & 1.0 & 0.9 & 0.7 & 3.8 & 1.4 & 1.2 \\
\hline $\mathrm{Ca}$ & 2.5 & 2.3 & 4.2 & 5.4 & 2.5 & 1.3 & 3.0 & 1.5 & 7.7 & 6.1 & 5.8 & 8.2 & 5.4 & 1.2 & 5.7 & 2.5 \\
\hline $\mathrm{Ti}$ & 1.0 & 0.8 & 0.6 & 0.7 & 0.7 & 0.9 & 0.8 & 0.1 & 0.4 & 0.5 & 0.4 & 0.7 & 0.3 & 0.9 & 0.5 & 0.2 \\
\hline $\mathrm{V}$ & 101.5 & 96.9 & 97.5 & 95.0 & 94.2 & 154.3 & 106.6 & 23.5 & 91.6 & 96.9 & 108.3 & 97.1 & 82.1 & 149.5 & 104.2 & 23.7 \\
\hline $\mathrm{Cr}$ & 49.8 & 48.7 & 47.9 & 46.2 & 46.9 & 102.1 & 57.0 & 22.2 & 54.2 & 41.6 & 45.2 & 47.5 & 33.5 & 100.1 & 53.7 & 23.7 \\
\hline $\mathrm{Mn}$ & 692.1 & 635.1 & 1025.6 & 1164.9 & 643.7 & 856.9 & 836.4 & 220.3 & 4329.6 & 6823.7 & 5445.9 & 2727.2 & 3740.0 & 819.3 & 3980.9 & 2096.4 \\
\hline $\mathrm{Fe}$ & 4.5 & 4.0 & 4.8 & 5.4 & 4.0 & 7.0 & 5.0 & 1.1 & 9.4 & 6.8 & 8.0 & 8.9 & 5.4 & 6.8 & 7.5 & 1.5 \\
\hline Co & 12.9 & 10.7 & 7.9 & 14.6 & 12.0 & 24.0 & 13.7 & 5.5 & 24.4 & 13.0 & 18.7 & 23.1 & 12.6 & 23.3 & 19.2 & 5.3 \\
\hline $\mathrm{Ni}$ & 29.4 & 25.8 & 21.7 & 32.3 & 30.1 & 59.0 & 33.0 & 13.2 & 45.6 & 37.1 & 36.3 & 44.7 & 25.8 & 56.9 & 41.1 & 10.6 \\
\hline $\mathrm{Cu}$ & 45.7 & 33.1 & 27.6 & 41.8 & 43.5 & 32.9 & 37.4 & 7.2 & 5.3 & 7.5 & 5.4 & 4.3 & 2.8 & 31.4 & 9.5 & 10.8 \\
\hline $\mathrm{Zn}$ & 88.5 & 68.2 & 112.2 & 104.2 & 223.0 & 172.8 & 128.2 & 58.3 & 7.5 & 25.1 & 10.1 & 11.3 & 7.7 & 164.6 & 37.7 & 62.5 \\
\hline $\mathrm{Ge}$ & 1.8 & 2.0 & 2.5 & 2.5 & 2.4 & 2.7 & 2.3 & 0.3 & 2.2 & 2.1 & 1.5 & 1.8 & 1.1 & 2.5 & 1.9 & 0.5 \\
\hline As & 16.5 & 16.7 & 8.4 & 15.8 & 19.5 & 13.8 & 15.1 & 3.8 & 0.2 & 0.3 & 0.3 & 0.5 & 0.4 & 11.4 & 2.2 & 4.5 \\
\hline $\mathrm{Se}$ & 1.2 & 1.2 & 0.7 & 1.3 & 1.2 & 2.6 & 1.4 & 0.7 & bd & bd & 0.9 & 0.7 & 1.1 & 2.5 & 1.3 & 0.8 \\
\hline $\mathrm{Sr}$ & 125.4 & 113.2 & 168.0 & 209.9 & 129.9 & 122.0 & 144.7 & 37.1 & 211.8 & 167.6 & 164.6 & 255.4 & 150.3 & 112.8 & 177.1 & 49.9 \\
\hline Mo & 14.6 & 13.3 & 14.7 & 16.6 & 16.6 & 0.7 & 12.8 & 6.0 & 4.5 & 3.8 & 2.5 & 7.2 & 3.3 & 1.2 & 3.8 & 2.1 \\
\hline $\mathrm{Ag}$ & 0.1 & 0.1 & 0.1 & 0.2 & 0.1 & 0.1 & 0.1 & 0.0 & 0.7 & 0.1 & 0.1 & 0.2 & 0.1 & 0.5 & 0.3 & 0.2 \\
\hline $\mathrm{Cd}$ & 2.4 & 1.2 & 1.0 & 1.3 & 1.8 & 0.3 & 1.3 & 0.7 & 0.2 & 0.3 & 0.0 & 0.8 & 0.4 & -0.2 & 0.2 & 0.3 \\
\hline $\mathrm{Sn}$ & 5.0 & 5.1 & 5.0 & 5.0 & 5.2 & 3.9 & 4.9 & 0.5 & 2.6 & 3.1 & 3.1 & 3.1 & 2.0 & 4.1 & 3.0 & 0.7 \\
\hline $\mathrm{Sb}$ & 1.3 & 1.0 & 0.8 & 1.2 & 1.1 & 1.2 & 1.1 & 0.2 & 0.7 & 0.1 & 0.3 & 0.5 & 0.3 & 1.0 & 0.5 & 0.3 \\
\hline $\mathrm{Ba}$ & 703.0 & 678.0 & 727.6 & 723.7 & 724.4 & 472.6 & 671.6 & 99.3 & 108.7 & 69.5 & 77.3 & 144.8 & 56.1 & 474.6 & 155.2 & 159.7 \\
\hline $\mathrm{Re}$ & 0.1 & 0.1 & 0.0 & 0.0 & 0.0 & 0.0 & 0.1 & 0.1 & 0.0 & 0.0 & 0.2 & 0.1 & 0.0 & 0.0 & 0.1 & 0.1 \\
\hline $\mathrm{Au}$ & 0.0 & 0.0 & 0.0 & 0.0 & 0.2 & 0.0 & 0.1 & 0.1 & 0.0 & 0.0 & 0.0 & 0.0 & bd & 0.0 & 0.0 & 0.0 \\
\hline $\mathrm{Hg}$ & 719.7 & 609.5 & 492.3 & 615.6 & 495.1 & 518.0 & 575.0 & 89.7 & 255.6 & 451.4 & 460.8 & 518.0 & 306.9 & 528.5 & 420.2 & 113.0 \\
\hline $\mathrm{Pb}$ & 25.9 & 25.9 & 13.8 & 26.3 & 22.0 & 36.5 & 25.1 & 7.4 & 31.4 & 12.4 & 27.2 & 41.0 & 15.4 & 37.8 & 27.5 & 11.6 \\
\hline $\mathrm{Bi}$ & 1.6 & 1.5 & 0.8 & 1.7 & 1.4 & 0.5 & 1.2 & 0.5 & 1.1 & 0.6 & 1.0 & 1.3 & bd & 0.5 & 0.9 & 0.4 \\
\hline Th & 15.5 & 15.6 & 20.3 & 15.1 & 15.1 & 12.1 & 15.6 & 2.6 & 9.0 & 12.6 & 11.0 & 13.4 & 8.3 & 15.9 & 11.7 & 2.9 \\
\hline $\mathrm{U}$ & 7.2 & 6.9 & 6.7 & 6.6 & 6.9 & 3.2 & 6.3 & 1.5 & 3.1 & 4.1 & 3.5 & 4.2 & 2.1 & 3.3 & 3.4 & 0.8 \\
\hline
\end{tabular}

